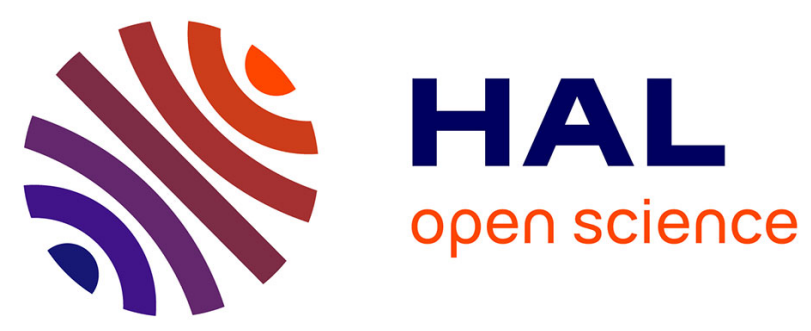

\title{
Nitrogen in peridotite xenoliths: Lithophile behavior and magmatic isotope fractionation
}

\author{
R. Yokochi, B. Marty, Gilles Chazot, Pete Burnard
}

\section{To cite this version:}

R. Yokochi, B. Marty, Gilles Chazot, Pete Burnard. Nitrogen in peridotite xenoliths: Lithophile behavior and magmatic isotope fractionation. Geochimica et Cosmochimica Acta, 2009, 73 (16), pp.4843-4861. 10.1016/j.gca.2009.05.054 . insu-00429529

\section{HAL Id: insu-00429529 \\ https://hal-insu.archives-ouvertes.fr/insu-00429529}

Submitted on 4 Nov 2009

HAL is a multi-disciplinary open access archive for the deposit and dissemination of scientific research documents, whether they are published or not. The documents may come from teaching and research institutions in France or abroad, or from public or private research centers.
L'archive ouverte pluridisciplinaire HAL, est destinée au dépôt et à la diffusion de documents scientifiques de niveau recherche, publiés ou non, émanant des établissements d'enseignement et de recherche français ou étrangers, des laboratoires publics ou privés. 


\section{Nitrogen in peridotite xenoliths: lithophile behavior and magmatic isotope fractionation}

Reika Yokochi $^{1^{*}}$, Bernard Marty ${ }^{2}$, Gilles Chazot ${ }^{3,4}$ and Pete Burnard ${ }^{2}$

1: Department of Earth and Environmental Sciences, University of Illinois at Chicago, 845 W. Taylor Street, MC186, SES2440, Chicago, IL 60607, U.S.A.

2: Centre de Recherches Pétrographiques et Géochimiques, Nancy Université, CNRS, BP 20, 54501 Vandoeuvre Cedex France

3: Université Européenne de Bretagne, France.

4: Université de Brest ; CNRS ; UMR 6538 Domaines Océaniques; Institut Universitaire Européen de la Mer, Place Copernic, 29280 Plouzané, France

* Corresponding author (yokochi@uic.edu) 


\section{Abstract}

In order to document the origin and speciation of nitrogen in mantle-derived rocks and minerals, the $\mathrm{N}$ and Ar contents and isotopic compositions were investigated for hydrous and anhydrous peridotite xenoliths from Ataq, Yemen, from Eifel, Germany, and from Massif Central, France. $\mathrm{N}$ and Ar were extracted by stepwise combustion with a fine temperature resolution, followed by fusion in a platinum crucible. A large isotopic disequilibrium of up to $25.4 \%$ is observed within single peridotite xenoliths, with $\delta^{15} \mathrm{~N}$ value as low as $-17.3 \%$ in phlogopite whereas clinopyroxene and olivine show positive $\delta^{15} \mathrm{~N}$ values. Identical Sr isotopic ratios of phlogopite, clinopyroxene and whole rock in this wehrlite sample are consistent with crystallization from a common reservoir, suggesting that the light $\mathrm{N}$ signature of phlogopite might be the result of isotopic fractionation during $\mathrm{N}$ uptake from the host magma. The $\mathrm{N}$ concentration is systematically high in phlogopite, (7.6 - $25.7 \mathrm{ppm})$, whereas that of bulk peridotite xenoliths is between $0.1 \mathrm{ppm}$ and $0.8 \mathrm{ppm}$. The high $\mathrm{N}$ content of phlogopite is at least partly due to host magma-mineral interaction, but may also suggest the occurrence of $\mathrm{N}$ as $\mathrm{NH}_{4}^{+}$in mafic magmas, that substituted to $\mathrm{K}^{+}$during mineral growth. Such speciation is consistent with the fact that $\mathrm{N}$ and $\mathrm{Rb}$ contents correlate well for a set of samples from mantle regions that were affected by subduction-related metasomatism and magmatism. The N/Rb ratios of these samples are comparable to values estimated for subduction zone magmas, but are one order of magnitude lower than the $\mathrm{N} / \mathrm{Rb}$ ratios characterizing subducting slabs. This difference is consistent with preferential release of $\mathrm{N}$ relative to alkalis in the forearc region. $\mathrm{N} /{ }^{40} \mathrm{Ar} *$ ratios of minerals from analyzed mantle xenoliths are much higher than those of vesicles in MORBs and OIBs, requiring either the occurrence of $\mathrm{N}$ speciation in the mantle more compatible than Ar, significant loss of fluid phase during entrainment, or long residence time of volatile elements in the mantle source(s) of fluids to increase drastically the ${ }^{40} \mathrm{Ar} *$ budget of the latter. 


\section{Introduction}

Nitrogen is a major constituent of the atmosphere and of organic molecules. The availability and speciation of this element at the Earth's surface had therefore been a major controlling factor for the evolution of the Earth's atmosphere, hydrosphere and biosphere. Furthermore, the diversity of $\mathrm{N}$ isotopic compositions among potential Earth building matter makes this element a potential tracer for the source of terrestrial volatile elements. Nitrogen in fluid inclusions of Mid-Ocean Ridge Basalts (MORB) sampling the underlying mantle and of fibrous diamonds derived from the subcontinental mantle is depleted in ${ }^{15} \mathrm{~N}$ by a few parts per mil relative to the atmosphere $\left(\delta^{15} \mathrm{~N}_{\mathrm{ATM}}=-3\right.$ to $-7 \%$ : Javoy et al., 1984: Boyd et al., 1987: Javoy and Pineau, 1991: Marty and Humbert, 1997: Nishio et al., 1999: Marty and Zimmermann, 1999). Javoy et al. (1984) proposed that the light $\mathrm{N}$ component in the mantle is a remnant of a $\mathrm{N}$ isotopic composition found in enstatite chondrites $\left(\delta^{15} \mathrm{~N}=-30\right.$ to $-40 \%$ ). This interpretation assumes that the $\mathrm{N}$ isotopic composition of mantle-derived samples represents a primordial signature, by analogy with light noble gases. Low $\delta^{15} \mathrm{~N}$ values down to $-25 \%$ have been observed in diamonds, which was interpreted to support this hypothesis (Cartigny et al., 1997).

The survival of a primordial $\mathrm{N}$ isotope signature depends on the recycling efficiency of this element into the mantle. Hilton et al. (2002) estimated that the flux of $\mathrm{N}$ arriving at subduction zones is $4.5 \times 10^{10} \mathrm{~mol} / \mathrm{yr}$, whereas the flux released by arc magmatism is $2.0 \times$ $10^{10} \mathrm{~mol} / \mathrm{yr}$, based on an extensive data compilation of worldwide arcs. The difference $(2.5 \times$ $10^{10} \mathrm{~mol} / \mathrm{yr}$ ) would represent the fraction of $\mathrm{N}$ either lost in fore-arc region, or subducted back into the mantle. Studies of metamorphic rocks and local volcanic flux suggest either significant (78-94\%: Haendel et al., 1986; Bebout and Fogel, 1992; Mingram and Brauer, 2001; Sadofsky and Bebout, 2004) or insignificant (Fischer et al., 2002; Sadofsky and Bebout, 2003; Busigny et al., 2003) losses of $\mathrm{N}$ in subduction zones, the rest $(6-100 \%, 0.15-2.5 \times$ 
$10^{10} \mathrm{~mol} / \mathrm{yr}$ ) being recycled into the mantle. Nitrogen recycling through subduction was independently proposed from variations of the $\mathrm{N}_{2}{ }^{36} \mathrm{Ar}$ ratios (Dauphas and Marty, 1999: Marty and Dauphas, 2003): Contrary to ${ }^{40} \mathrm{Ar}$ which is continuously produced in the mantle by the decay of ${ }^{40} \mathrm{~K},{ }^{36} \mathrm{Ar}$ in the mantle is considered to be primordial, that is, trapped in the Earth during accretion. Assuming that $\mathrm{N}$ and Ar behave concomitantly during geological processes except subduction, the observation that the $\mathrm{N}_{2}{ }^{36} \mathrm{Ar}$ ratio of the mantle is two orders of magnitude higher than that of the atmosphere (the main noble gas reservoir on Earth) was interpreted as a result of the selective $\mathrm{N}$ recycling into the mantle. Notably, these authors suggested that the $\mathrm{N}$ isotopic variation of different mantle domains was the result of subduction of sediments which $\mathrm{N}$ isotope compositions changed with time, reflecting change in the oxidation state of the Earth's surface (Marty and Dauphas, 2003).

It has long been recognized that the major fraction of $\mathrm{N}$ in the oceanic crust is trapped in sediments as organic molecules. During diagenesis, $\mathrm{N}$ forms ammonium that substitutes $\mathrm{K}$ in diagenetic minerals (Honma and Itihara, 1981; Itihara and Honma, 1979; Williams et al., 1995; Boyd et al., 1993). Thereby, $\mathrm{N}$ becomes a lithophile element in the geochemical cycle. However, $\mathrm{N}$ in mantle-derived fluids (volcanic gases, vesicles in volcanic glasses and in phenocrysts) appears to be mainly present as $\mathrm{N}_{2}$, and shows an atmophile behavior similar to that of noble gases (Marty, 1995). It is currently not well understood whether subducted ammonium transforms into molecular $\mathrm{N}$ before reaching the mantle so that mantle is free of ammonium, or if $\mathrm{N}$ exists in the form of ammonium in the mantle, which may require revision of the mantle $\mathrm{N}$ budget.

Peridotite xenoliths provide a unique opportunity to investigate the characteristics (speciation and isotopic composition) of $\mathrm{N}$ in the lithospheric mantle. Furthermore, they also occasionally present overprints of mantle fluids and/or of host magmas of asthenospheric origin, allowing the behavior of $\mathrm{N}$ during mantle processes to be investigated. Yet, data on the 
$\mathrm{N}$ isotopic composition of peridotite xenoliths are scarce. Two studies of $\mathrm{N}$ and $\mathrm{Ar}$ in fluid inclusions showed $\delta^{15} \mathrm{~N}$ values similar to that of oceanic basalts with slightly high $\mathrm{N}_{2} / \mathrm{Ar}$ ratios (Matsumoto et al., 2002; Fischer et al., 2005), whereas the data obtained by $\mathrm{N}$ extraction upon melting scatter significantly from -15.3 \%o up to $+30 \%$ (Huang, 1997: Mohapatra and Murty, 2000: 2002). Consequently, some of these values could have been biased due to (i) contamination by surface N (Marty, 1995), (ii) kinetic effects during gas extraction (Boyd et al., 1993: Pinti et al., 2007), or (iii) analytical bias due to the use of Nreactive metals (Yokochi and Marty, 2006). In order to address these problems, we have analyzed peridotite xenoliths by detailed stepwise combustion, followed by total fusion in a platinum crucible. Argon concentrations and isotopic compositions were also analyzed from the same gas fractions in order to investigate the degree of atmospheric contamination, the source(s) of N, and N speciation in magmatic conditions. Some of the samples were crushed under vacuum to extract gases trapped in fluid inclusions.

\section{Samples}

Samples were selected from three different lithospheric mantle regions: (i) Ataq, Bir Ali (Yemen), (ii) Dreis Weiher, Meerfelder Maar (Eifel, Germany), and (iii) Le Fau (Massif Central, France). The underlying mantle domains underwent variable extents of mantle metasomatism, triggered by the Afar plume, and the Hercynian and Variscan orogenies, respectively, as discussed below (Table 1).

\subsection{Yemen: $J K 2, J K 3, J K 7, J K 8$ and $B A 8$}

Mantle xenoliths were sampled at two Plio-Quaternary volcanic fields on the south coast of Yemen (Chazot et al., 1996b; 1997): Bir Ali (BA8) and Ataq (JK2, JK3, JK7 and JK8). BA8 is an anhydrous spinel lherzolite that represents the unmetasomatized component 
of this region. JK7 and JK8 are hydrous amphibole-bearing lherzolites recording a metasomatic event. Amphibole crystals, up to several millimetres large, are disseminated in the lherzolitic matrix and most of the time developed around spinel. Clinopyroxene is a chrome diopside also formed during metasomatism. Among these samples, JK3, JK7 and JK8 contain large (up to $2 \mathrm{~mm}$ ) apatite crystals also disseminated in the peridotite. Trace element study of the minerals coupled with isotopic data has shown that the metasomatic minerals (i.e. amphibole, clinopyroxene and apatite) are in chemical equilibrium in all the lherzolites (Chazot et al., 1996b). Very high incompatible element contents of these metasomatic minerals coupled with low $\mathrm{Zr}, \mathrm{Nb}$ and $\mathrm{Ti}$ contents have been interpreted as evidence for metasomatism involving a carbonated fluid (Chazot et al., 1996b). Based on Sr-Nd-Pb isotopic compositions, Baker et al. (1998) suggested that the metasomatic event affecting these samples was related to the Afar mantle plume. Helium and neon isotopic compositions of the metasomatic minerals also suggest a minor contribution of the Afar plume component (Yokochi et al., 2002). A common characteristic of these samples is the isochemical decompression melting that is evident as either interstitial glass or melt-pockets formed around residual amphibole grains (Chazot et al., 1996a).

\subsection{Massif Central: F100}

F100 is a metasomatized spinel harzburgite from the Massif Central. Mantle xenoliths are present in many localities in France. They often show evidence for metasomatism, either related to the Hercynian orogeny or to Tertiary to Quaternary extensive intraplate volcanism. F100 contains large crystals of amphibole and some phlogopite grains disseminated in the harzburgitic matrix. REE compositions of amphiboles show convex upward patterns. Amphibole also has very low $\mathrm{Rb}$ and $\mathrm{Th}$ concentrations, but high $\mathrm{Ba}$ contents, suggesting that recycled pelagic sediments contributed to the source of the metasomatic fluid. 


\subsection{Eifel: DU24, DU 25, DU26, MM2 and MM13}

The isotope signatures of Cenozoic volcanics in Europe suggest the presence of subducted material in the European subcontinental mantle (Worner et al., 1986; Wilson and Downes, 1991), and the peridotite xenoliths from these regions had gone through a variety of metasomatic events (e.g. Stoch and Seck, 1980; Witt-Eickschen et al., 1993; Witt-Eickschen et al., 2003). Peridotite xenoliths from Dreis Weiler (abbreviation DU in sample name) and Meerfelder Maar (abbreviation MM in sample name) have been classified into four groups. These are: (i) LREE-depleted anhydrous lherzolites and harzburgites, which are partial melting residues of the fertile mantle (Stosch and Seck, 1980); (ii) Hydrous and anhydrous harzburgites characterized by LREE enrichment of clinopyroxene (Stosch and Seck, 1980: Stosch and Lugmair, 1986) and occasional formation of pargasitic amphibole (Witt and Seck, 1989; Witt-Eickschen et al., 1998a), which were due to a fluid triggered metasomatism of the depleted mantle region; (iii) pyroxenite and Ti-rich hornblendite veins and cumulates that formed during subsequent Quaternary volcanism (Witt et al., 1989; Witt-Eickschen et al., 1998a). The formation of veins was accompanied by limited alteration (e.g. Ti-enrichment: Witt-Eickschen et al., 1998b) of the host peridotites; (iv) phlogopite-bearing wehrlites that were suggested to be reaction products between Quaternary magma and wall rocks (Lloyd and Bailey, 1975: Stosch and Lugmair, 1986).

Two of our anhydrous samples (DU25 and MM2) are characterized by high La/Sm and $\mathrm{Sm} / \mathrm{Zr}$ ratios attributed to a fluid-triggered metasomatism, which classifies them into group (ii). Similar $\mathrm{La} / \mathrm{Sm}$ and $\mathrm{Sm} / \mathrm{Zr}$ signatures were observed for amphibole-bearing harzburgite MM13. The amphiboles in this sample, however, contain a moderate amount of $\mathrm{Ti}(1.5 \%)$, intermediate between pargasite formed by an early fluid related to metasomatism and hornblende formed recently during the Quaternary Eifel volcanism (Witt and Seck, 1989; Witt-Eickschen et al., 1998a). This suggests that amphibole was formed during the first fluid- 
triggered event, then partially altered during recent magmatism. Thus this sample is intermediate between groups (ii) and (iii).

Two phlogopite-bearing wehrlites (DU24, DU26) belong to group (iv). DU24 and DU26 are similar in mineralogy, consisting of olivine, clinopyroxene, spinel and phlogopite. DU26 additionally contains apatite, and a thin phlogopite vein was observed in this sample. They have concave REE abundance patterns (normalized to the primitive mantle) and nearchondritic $\mathrm{Sm} / \mathrm{Zr}$ ratios of clinopyroxenes, which suggests that fluid contribution was limited. In DU24, Sr isotopic compositions were identical for clinopyroxene, phlogopite and whole rock (Table 2 ). $\mathrm{Rb}$ concentrations vary significantly by more than two orders of magnitude among minerals, and identical $\mathrm{Sr}$ isotope signature of these mineral phases indicates that the formation of this wehrlite occurred recently $(<0.5 \mathrm{Ma})$, probably related to Quarternary volcanism. Wehrlite containing Fe-rich olivine forms by interaction between mantle rocks (very often harzburgites) with large volume of silicate melt percolating through the mantle (Raffone et al., 2009), and such occurrence was proposed for a wehrlite from this locality (Stosch and Lugmair, 1986).

\section{Analytical methods}

Samples were cleaned ultrasonically in acetone, wrapped in $\mathrm{Pt}$ foil for heating extraction, and pre-heated at $200{ }^{\circ} \mathrm{C}$ under ultrahigh vacuum for at least $12 \mathrm{~h}$ before analysis. Mineral separates and small chunks $(<5 \mathrm{~mm})$ of bulk rock were analyzed by step-wise combustion $\left(f_{\mathrm{O} 2} \approx 0.1\right.$ mbar from $\mathrm{CuO}$ ) up to $1100{ }^{\circ} \mathrm{C}$ in a double-walled quartz tubing furnace. $\mathrm{O}_{2}$ helped removing organic phases that are source of $\mathrm{N}$ contamination. Samples were subsequently transferred from the quartz furnace to an induction furnace under vacuum, where they were melted at $1350-1650^{\circ} \mathrm{C}$. The heating duration was 30 minutes. Because Mo and Ta are highly reactive with N (Yokochi and Marty, 2006), a Pt crucible was used. The 
melting temperature of $\mathrm{Pt}$ limited the operating temperature of induction furnace to $1650{ }^{\circ} \mathrm{C}$, below that of olivine. A degassed silicate glass was used as a flux in order to decrease the melting point of refractory minerals. Bulk samples were covered only halfway with the Pt foil to facilitate mixing with the flux. The Pt foils wrapping mineral separates were pierced for the same purpose. Although melting was visually confirmed, the highest temperature step was repeated in most cases until there was no further significant $\mathrm{N}$ release. Blanks were $2-5 \times 10^{-12}$ mol $\mathrm{N}_{2}$ and $2 \times 10^{-14} \mathrm{~mol}^{40} \mathrm{Ar}$ for temperatures below $900^{\circ} \mathrm{C}, 1.5-3 \times 10^{-11} \mathrm{~mol} \mathrm{~N}_{2}$ and $3-6 \times$ $10^{-13} \mathrm{~mol}^{40} \mathrm{Ar}$ for temperatures in the range $900-1100{ }^{\circ} \mathrm{C}$, and $1-7 \times 10^{-10} \mathrm{~mol} \mathrm{~N}_{2}$ and $0.27-$ $12.0 \times 10^{-12} \mathrm{~mol}^{40} \mathrm{Ar}$ for the induction furnace at $1350-1600{ }^{\circ} \mathrm{C}$.

Crushing gas extraction was applied for some of samples from Yemen and for one sample from Eifel (Table 3). Samples weighing between $0.5 \mathrm{~g}$ and $1.0 \mathrm{~g}$ were cleaned ultrasonically in acetone, then loaded in crushing tubes and heated at $150-200{ }^{\circ} \mathrm{C}$ overnight under high vacuum. Crushing was performed on-line with an iron slug activated by three external solenoids (Richard et al., 1996) for variable duration (Table 3). The stroke frequency was 100/min. The extracted gas was split into two fractions, for $\mathrm{N}$ and noble gases, and purified using $\mathrm{CuO}_{\mathrm{x}}$ and Ti sponge, respectively. Blanks were 4-6 $\times 10^{-12} \mathrm{~mol} \mathrm{~N}_{2}$ and 0.5-3.5 $\times 10^{-13} \mathrm{~mol}^{40} \mathrm{Ar}$.

\section{Results}

The two extraction methods (heating and crushing) release $\mathrm{N}$ from different sites. Vacuum crushing releases preferentially $\mathrm{N}$ trapped in fluid inclusions, whereas stepwise combustion (e.g., heating under an atmosphere of pure oxygen) is aimed at separating $\mathrm{N}$ trapped in low retentivity phases such as organics or adsorbed atmospheric $\mathrm{N}$, from $\mathrm{N}$ trapped in the crystalline network of silicates. Extraction of $\mathrm{N}$ by pyrolysis (heating samples under high vacuum without oxygen) was not used in this study because it is likely to cause 
evaporation of organic compounds from the samples which might have recondensed on the walls of the vacuum line. Such process is prone to isotopic fractionation and cross contamination for subsequent runs.

\subsection{Crushing extraction}

Data for $\mathrm{N}$ and $\mathrm{Ar}$ concentrations and ${ }^{40} \mathrm{Ar} /{ }^{36} \mathrm{Ar}$ ratios of olivine separated from sample JK2, JK3 and JK8 (Yemen) as well as clinopyroxene from JK7 (Yemen) and DU25 (Eifel) are listed in Table 3. The $\mathrm{N}_{2} /{ }^{40} \mathrm{Ar}$ ratios of gases extracted by crushing of mineral separates varied between 57 and 151, consistent with ratios around $100 \pm 50$ obtained by crushing oceanic basalts and minerals from mantle plume and mid-ocean ridge provinces (e.g. Marty, 1995; Marty and Dauphas, 2003), but lower than ratios observed in some peridotite xenoliths (up to 309: Matsumoto et al., 2002; Fischer et al., 2005). Yemen samples show lower ${ }^{40} \mathrm{Ar} /{ }^{36} \mathrm{Ar}$ ratios from 360 to 936 , and a positive correlation between ${ }^{40} \mathrm{Ar} /{ }^{36} \mathrm{Ar}$ and $\mathrm{N}_{2} /{ }^{40} \mathrm{Ar}$ (Fig 1). The low ${ }^{40} \mathrm{Ar} /{ }^{36} \mathrm{Ar}$ end-member has a composition close to that of the unfractionated atmosphere $\left({ }^{40} \mathrm{Ar} /{ }^{36} \mathrm{Ar}=295.5, \quad \mathrm{~N}_{2} /{ }^{40} \mathrm{Ar}=83.1\right)$, strongly suggesting contribution of an atmospheric component. This correlation also suggests that the ${ }^{40} \mathrm{Ar} /{ }^{36} \mathrm{Ar}$ and $\mathrm{N}_{2} /{ }^{40} \mathrm{Ar}$ ratios of the magmatic fluid is higher than the highest ratios observed, which are 936 and 151, respectively. Stepwise-crushing analysis of DU25 clinopyroxene yielded high ${ }^{40} \mathrm{Ar} /{ }^{36} \mathrm{Ar}$ ratios (up to 7418 ), indicating that fluid inclusions have preserved trapped mantle volatiles from exchange with atmospheric Ar in the host magma.

The amounts of $\mathrm{N}$ recovered upon crushing, which represent $\mathrm{N}$ trapped in fluid inclusions, are much lower than those recovered following heating of mantle xenoliths (see Table 3 and 4). Olivine from Ataq (JK2-8) yielded $\sim 2 \times 10^{-10} \mathrm{~mol} \mathrm{~N}_{2} / \mathrm{g}(6 \mathrm{ppb})$, whereas one clinopyroxene (JK7) was richer in $\mathrm{N}$ by a factor of 4 . One sample from Bir Ali (BA8) was depleted in $\mathrm{N}$ by about an order of magnitude for both olivine and clinopyroxene compared to 
metasomatized samples from neighboring locality, Ataq. One sample rich in fluid inclusion, clinopyroxene from DU25, yielded about twice as much $\mathrm{N}$ as that from JK7.

\subsection{Heating extraction}

\subsubsection{Release patterns and concentrations of $N$}

For refractory minerals (olivine, clinopyroxene, amphibole), the yield of released $\mathrm{N}$ decreased until $900{ }^{\circ} \mathrm{C}$, and subsequently increased toward the melting temperature of the analyzed phases (Fig 2, Table 4). Such a release pattern indicates that there are two different $\mathrm{N}$ components released from a single sample, one almost completely combusted at temperatures lower than $900{ }^{\circ} \mathrm{C}$, and the other one that starts to mobilize at $\mathrm{T}>900{ }^{\circ} \mathrm{C}$. Mantle volatiles are likely to be released at high temperatures comparable to those of the ambient mantle temperature. Decrepitation of fluid inclusions below this temperature is unlikely to dominate the $\mathrm{N}$ isotope signature because our crushing experiments shows clearly distinct $\mathrm{N}_{2} /{ }^{40} \mathrm{Ar}$ ratios from heating ones. Phases combusted at low temperature are not stable in the mantle, and a contaminant origin for this low $\mathrm{T}$ component is independently supported by lower ${ }^{40} \mathrm{Ar} /{ }^{36} \mathrm{Ar}$ ratios for $\mathrm{T}<900^{\circ} \mathrm{C}$ compared to high $\mathrm{T}$ extractions. We therefore consider that $\mathrm{N}$ extracted above $900^{\circ} \mathrm{C}$ represents best the trapped $\mathrm{N}$ component, in the case of most refractory phases.

Phlogopite samples display a N-extraction pattern analogous to that of neutroninduced ${ }^{39} \mathrm{Ar}$ (well studied for chronological purposes, e.g. Gaber et al., 1988): significant release starts around $800{ }^{\circ} \mathrm{C}$ and peaks at $900-1000{ }^{\circ} \mathrm{C}$ (Fig 2). Whole rock samples without mica show release patterns similar to that of the refractory minerals (Fig 1), as expected. Exceptions are samples from Yemen characterized by $\mathrm{N}$ release peaks at $900{ }^{\circ} \mathrm{C}$, probably from Cl-rich apatite grains and/or interstitial glass (Chazot et al., 1996a,b). The concentrations of $\mathrm{N}$ in phlogopite (7.6 - $25.7 \mathrm{ppm})$ are typically $>50$ times higher than those in co-existing 
refractory minerals (0.1-0.2 ppm), while amphibole $\mathrm{N}$ concentrations are intermediate. Nitrogen contents of bulk peridotite xenoliths vary depending on mineralogy (i.e. presence or absence of mica), but never exceed $1 \mathrm{ppm}$.

\subsubsection{Argon isotopic composition and $\mathrm{N}_{2}{ }^{A 0}$ Ar ratios}

Contamination of magmas by atmospheric Ar is well documented by K-Ar dating studies and during attempts to identify mantle noble gases from analysis of mantle-derived rocks. A rough correlation between ${ }^{40} \mathrm{Ar} /{ }^{36} \mathrm{Ar}$ and $1{ }^{36} \mathrm{Ar}$ (Fig 3) suggest a significant contribution of atmospheric Ar, attributed to the exchange of trapped radiogenic Ar in mantle minerals with atmospheric Ar from the host magma (e.g. Kelley and Wartho, 2000). Such an effect is more pronounced for phlogopite and amphibole than for refractory minerals. The total amounts of Ar released by crushing and heating are comparable, indicating that most Ar was in fluid inclusions, but more $\mathrm{N}$ was extracted by heating relative to crushing.

Heating extractions yielded much higher $\mathrm{N}_{2} /{ }^{40} \mathrm{Ar}$ ratios $(14,000$ on average of bulk xenoliths) than crushing (Fig. 4), indicating that $\mathrm{N}$ contamination from atmosphere is a less serious problem than in the case of Ar. Although crushing of limited number of samples released volatile elements with mantle fluid-like $\mathrm{N}_{2} /{ }^{40} \mathrm{Ar}$ ratios $(100 \pm 50$ : Marty and Dauphas, 2003), most heating runs have $\mathrm{N}_{2} /{ }^{40} \mathrm{Ar}>1000$, indicating that most of $\mathrm{N}$ in peridotites is not trapped in fluid inclusions, contrary to Ar.

\subsection{3 $N$ isotopic compositions}

The low temperature steps (the first ones in particular) release $\mathrm{N}$ with variable isotopic compositions (from -8 to $+8 \%$ ). These variations could be due to a combination of isotopic fractionation during sample preparation (e.g. cleaning) and/or pre-degassing processes and of variable surface contamination including adsorption. Kinetic isotopic fractionation is also apparent during stepwise extraction: phlogopite shows increase of $\delta^{15} \mathrm{~N}$ values with 
temperature, while other refractory minerals release light $\mathrm{N}$ before melting, and heavier $\mathrm{N}$ at melting. This effect is cancelled out when taking the sum of high temperature fractions. These results warn that the $\mathrm{N}$ isotopic compositions of temperature steps do not necessarily represent that of distinct trapped components, contrary to some previous interpretations (e.g. Mohapatra and Murty, 2003).

Trapped $\mathrm{N}$ in bulk peridotite xenoliths shows variable $\delta^{15} \mathrm{~N}$ values between $-7 \%$ and $+12 \%$. Samples from Yemen (JK7, JK8 and BA8) are characterized by high $\delta^{15} \mathrm{~N}$ values around $+10 \%$. Two samples related to fluid-triggered metasomatism in Eifel (DU25 and MM2) have $\delta^{15} \mathrm{~N} \approx+4 \%$, with elevated ${ }^{40} \mathrm{Ar} /{ }^{36} \mathrm{Ar}$ ratios. One sample from the Massif Central (F100) shows a comparable $\mathrm{N}$ isotopic ratio of $+6.4 \%$. A sample which possibly interacted with the host magma of Eifel (MM13) displays a somewhat lighter whole rock $\delta^{15} \mathrm{~N}$ value of $+0.4 \%$. Bulk rock analysis of phlogopite-bearing wehrlites (DU24 and DU26) show negative, MORB-like, $\delta^{15} \mathrm{~N}$ values, while these signatures are unlikely to represent an endmember but rather a result of a major contribution from light $\mathrm{N}$ in phlogopite (see below).

N-rich mineral separates (phlogopite and amphiboles) from two samples (DU26, F100) show $\mathrm{N}$ isotope signatures comparable to those of bulk peridotites, because $\mathrm{N}$ in these minerals dominates the total $\mathrm{N}$ contents. Bulk $\mathrm{N}$ isotopic compositions of sample DU24 and MM13 were clearly distinct from that of mineral separates. Correlations between $\delta^{15} \mathrm{~N}$ and ${ }^{40} \mathrm{Ar} /{ }^{36} \mathrm{Ar}$ ratios among mineral separates and bulk analyses of single rocks (Fig. 5) demonstrate interactions between minerals and a component characterized by atmospheric Ar. A large isotopic disequilibrium among mineral phases is observed in DU24, with $\delta^{15} \mathrm{~N}$ values ranging over $25 \%$ within a single rock and being positively correlated with ${ }^{40} \mathrm{Ar} /{ }^{36} \mathrm{Ar}$ ratios (Fig. 5b). The correlation is opposite in the case of sample MM13 (Fig. 5a), indicating that a simple two-component mixing cannot account for the two contrasted correlations. The bulk $\delta^{15} \mathrm{~N}$ value of MM13 is distinct from those of analyzed mineral separates (clinopyroxene, 
amphibole), suggesting that the $\mathrm{N}$ isotope compositions of olivine and/or orthopyroxene, which were not analyzed, are complementary (i.e. $<0 \%$ ) to those of analyzed phases.

\section{Discussion}

The high $\mathrm{N}$ content of phlogopite and the generally high $\mathrm{N}_{2} / \mathrm{Ar}$ ratio obtained by heating extraction of mineral phases relative to crushing extraction suggest that significant fraction of $\mathrm{N}$ may reside in mineral matrix, due either to superficial contamination, or to efficient partitioning of $\mathrm{N}$ relative to Ar. While the data obtained by vacuum crushing can only be affected by two component mixing of (i) mantle fluids and (ii) the secondary fluid inclusions from the host magma, exchange of elements between the mineral matrix and the host magma can be accompanied by kinetic isotope effects. In this section, possible interpretations of $\delta^{15} \mathrm{~N}$ data (Section 5.1) and implications of $\mathrm{N}$ abundance to global $\mathrm{N}$ distribution and cycle (Section 5.2), especially regarding $\mathrm{N}_{2} / \mathrm{Ar}$ and $\mathrm{N} / \mathrm{Rb}$ ratios, will be discussed.

\subsection{Secondary effects affecting $N$ isotopes in peridotite xenoliths}

The relatively low ${ }^{40} \mathrm{Ar} /{ }^{36} \mathrm{Ar}$ ratios of mantle peridotites relative to e.g. MORBs suggest that the peridotite xenoliths had been subject to volatile exchange with superficial components. Precedent works demonstrated that (i) fluids from host magma could be trapped in the fluid inclusions of peridotite xenoliths (Dunai and Baur, 1995), (ii) the mineral matrix can exchange volatile elements with the host magma, (e.g. Kelley and Wartho, 2000) and (iii) ascending magma could be gradually contaminated by atmospheric Ar (Farley and Craig, 1994). In an ascending magma, mantle minerals have ${ }^{40} \mathrm{Ar} /{ }^{36} \mathrm{Ar}$ ratios higher than atmospheric one that contaminates the host magma, thus diffusive mixing will continuously decrease ${ }^{40} \mathrm{Ar} /{ }^{36} \mathrm{Ar}$ ratios of mantle-derived minerals to different degrees, depending on the diffusivity, 
on the initial Ar contents, and on the size of the minerals. The ${ }^{40} \mathrm{Ar} /{ }^{36} \mathrm{Ar}$ ratios vary by two orders of magnitude in natural systems, thus the effect of kinetic isotope fractionation is always negligible compared to the variation caused by the mixing. The situation is different for $\mathrm{N}$ since $\delta^{15} \mathrm{~N}$ values only range only over a few tens of permil. In this subsection, we first attempt to set a limit on the range of the isotope fractionation, and constrain the evolution of the $\delta^{15} \mathrm{~N}$ values in the sample.

\subsubsection{Upper limit on isotope effect: Diffusive exchange}

Equilibrium isotope fractionation at magmatic temperatures cannot produce $\delta^{15} \mathrm{~N}$ variations of several per mil (Urey, 1947; Richet et al., 1977). Fischer et al. (2005) reported comparable $\delta^{15} \mathrm{~N}$ values for fumarole gases and for fluid inclusions in olivine phenocrysts at three different volcanic provinces, demonstrating that degassing does not fractionate $\mathrm{N}$ isotopes. Alternatively, diffusive fractionation could produce a significant isotope effect. For instance, hydrogen (up to $70 \%$ for amphibole; Deloule et al., 1991) and lithium (up to $23.6 \%$ for phlogopite; Jeffcoate et al., 2006) isotopic variations within minerals and among different phases of peridotite xenoliths were attributed to diffusive exchange of these elements between the host magma and minerals. Peslier and Luhr (2006) reported a significant loss of hydrogen during the ascent of the host magma even for olivine. Although the degree of such fractionation is expected to be smaller for $\mathrm{N}$ than for $\mathrm{H}$ or $\mathrm{Li}$ due to the smaller relative mass difference between isotopes, a similar process might have affected minerals in peridotite xenoliths.

The evolution of $\delta^{15} \mathrm{~N}$ in minerals was investigated using a diffusive mixing model. The model assumes that $\mathrm{N}$ from the host magma diffused into or out of a mineral phase, with the lighter isotope ${ }^{14} \mathrm{~N}$ diffusing faster than the heavier isotope ${ }^{15} \mathrm{~N}$. In the system, the mineral 
is in contact with a reservoir (or magma) with an equilibrium concentration of $\mathrm{C}_{\mathrm{liq}}{ }^{*}$ expressed as:

$$
\mathrm{C}_{\mathrm{liq}}{ }^{*}=\mathrm{C}_{\mathrm{liq}} \cdot \mathrm{Kd}_{\mathrm{min}}
$$

where $\mathrm{Kd}_{\min }$ is the partition coefficient of a $\mathrm{N}$-bearing species between the mineral and the host magma. When the equilibrium $\mathrm{N}$ content of the host magma, $\mathrm{C}_{\mathrm{liq}}{ }^{*}$, is different from that of the mineral $\left(\mathrm{C}_{\min , 0}\right)$, the ratio of the total amount of diffusing isotopes entering or leaving the mineral between time 0 and time $t\left(\mathrm{M}_{\mathrm{t}}\right)$ and at equilibrium $\left(\mathrm{M}_{\infty}\right)$ for infinite plane geometry can be determined using the following equation (Crank, 1975):

$\frac{M_{t}}{M_{\infty}}=1-\sum_{n=0}^{\infty} \frac{8}{(2 n+1)^{2} \pi^{2}} \exp \left(-D(2 n+1)^{2} \pi^{2} t / 4 l^{2}\right)$

where $D$ and $l$ are the diffusion coefficient of ${ }^{14} \mathrm{~N}$ and the thickness of the sheet, respectively. Instead of defining each parameter, $D t / l^{2}$ was varied to cover the entire isotopic evolution path for ${ }^{14} \mathrm{~N}$ and ${ }^{15} \mathrm{~N}$, respectively, to derive the isotope evolution. The isotopic fractionation was taken as proportional to a fractionation factor $\mathrm{f}$, i.e. $D$ was multiplied by $\mathrm{f}$ for ${ }^{15} \mathrm{~N}$. As it is unlikely that atomic $\mathrm{N}$ is stable in any geochemical environment, assuming ammonium diffusion $\left(f=(18 / 19)^{1 / 2}\right.$ rather than molecular $\mathrm{N}$ diffusion, i.e., $\left.f=(28 / 29)^{1 / 2}\right)$ yields the maximum possible isotope effect. As the system of concern is not free gas diffusion, the exponent of the fractionation factor could be smaller than $1 / 2$. Model results for molecular $\mathrm{N}$ diffusion with lower exponent $\left(\mathrm{f}=(28 / 29)^{1 / 4}\right)$ are also presented as lower limits.

Figure 6 (a) shows the modeled variations of $\Delta^{15} \mathrm{~N}$ (the isotopic deviation of $\mathrm{N}$ from an initial $\delta^{15} \mathrm{~N}$ (set as $0 \%$ ) in the mineral as diffusion proceeds) during $\mathrm{N}$ uptake as a function of the $\mathrm{C}_{\text {min, }} / \mathrm{C}_{\text {liq }}$ * ratio, for different values of (i) the initial $\mathrm{C}_{0, \min } / \mathrm{C}_{\text {liq }}{ }^{*}$ ratio (varying from 0.01 to $0.9)$ and (ii) $\delta^{15} \mathrm{~N}_{\text {liq }}\left(-20,-10,0,+10,+20 \%\right.$ ) with $\mathrm{f}=(18 / 19)^{1 / 2}$. It indicates that the $\mathrm{N}$ uptake temporarily decreases the $\delta^{15} \mathrm{~N}$ value. The negative shift is enhanced for lower $\mathrm{C}_{\min , 0}$ and extends as low as $\sim 12 \%$ below that of the host magma. Subsequently, the $\delta^{15} \mathrm{~N}$ value of the 
mineral increases towards that of the host magma. The opposite effect is observed for $\mathrm{N}$ loss from minerals (Fig. 6 (b)). $\mathrm{N}$ loss results in much larger positive $\delta^{15} \mathrm{~N}$ shift of up to $\sim+70 \%$ o due to a cumulative (distillation) effect when the initial concentration gradient is large, then $\delta^{15} \mathrm{~N}$ value of the mineral approaches to that of the host magma. These $\mathrm{N}$ isotope variations are of course more limited when the fractionation factor is smaller (Figure 6 (c) and (d), $f=$ $\left.(28 / 29)^{1 / 4}\right)$, and the range of the isotope variations becomes closer to that of simple mixing.

To summarize, $\mathrm{N}$ uptake from the host magma can bring the $\delta^{15} \mathrm{~N}$ value of the mineral up to $12 \%$ below that of the host magma, and the observed $\mathrm{N}$ isotopic composition of the mineral is the lower limit of the initial $\mathrm{N}$ isotopic composition when such negative $\delta^{15} \mathrm{~N}$ shift occurs. The $\delta^{15} \mathrm{~N}$ value of the mineral during $\mathrm{N}$ loss is always heavier than the lighter of the initial mineral and the host magma, setting lower limit on $\delta^{15} \mathrm{~N}$ value of one or both components

\subsubsection{Diffusive $N$ isotope fractionation in peridotite xenoliths}

In wehrlite DU24, a large inter-mineral isotopic variation (up to $25.4 \%$ o) was observed. As stated previously, $\mathrm{Sr}$ isotopic compositions of phlogopite, clinopyroxene and whole rock from this sample are identical within uncertainties, suggesting that these minerals crystallized from a common geochemical source. Furthermore, phlogopite, the phase with the lightest N (bulk $\delta^{15} \mathrm{~N}$ value of $-17.3 \%$ ) is the one that shows the most surface-contaminated $\mathrm{Ar}$ $\left({ }^{40} \mathrm{Ar} /{ }^{36} \mathrm{Ar}\right.$ close to the atmospheric value). Thus the isotopically light $\mathrm{N}$ component found in phlogopite can hardly represent a mantle pristine end-member, and the isotopic disequilibrium between different phases resulted probably from an isotopic fractionation process after, or during, formation of this wehrlite, affecting $\mathrm{N}$ but not $\mathrm{Sr}$.

Whether these minerals in peridotite xenoliths from Eifel were in equilibrium with the host magma and with each other for $\mathrm{N}$ can be determined by comparing the elemental abundances and isotopic compositions of minerals. Phlogopites from wehrlites DU24 and 
DU26 differs in $\mathrm{N}$ concentrations and isotopic compositions by about $50 \%$ and $15 \%$, respectively, indicating that magma-mineral equilibrium was not attained for phlogopite. The upper limit of the negative isotope excursion is $\sim 12 \%$ below that of host magma according to the model described in previous section. Thus the $\delta^{15} \mathrm{~N}$ value of the host magma needs to be $<-5 \%$ to attain the $\mathrm{N}$ isotopic composition of the DU24 phlogopite. This value is similar to that of the phlogopite in sample DU26 characterized by higher $\mathrm{N}$ concentration, which may imply that this phlogopite is close to $\mathrm{N}$-equilibrium with the host magma.

The $\mathrm{N}$ isotopic compositions of the other mineral phases may reflect the original $\mathrm{N}$ isotopic compositions of these phases in the mantle, or might have resulted from mixing between mineral phases and the host magma, accompanied by isotopic fractionation. If $\mathrm{N}$ in these minerals was under ammonium speciation, the equilibrium concentration may be estimated based on the partition coefficient of $\mathrm{Rb}$ which ionic radius is comparable to that of ammonium. Studies of natural and synthetic minerals led to establish values of $\mathrm{Rb}$ partition coefficients in olivine, clinopyroxene, amphibole and phlogopite of $\sim 0.02,0.04,0.2$ and 2.5, respectively (LaTourrette et al., 1995; Lemarchand et al., 1987; Irving and Frey, 1984; Adam et al., 1993). If phlogopite from sample DU26 containing $25.6 \mathrm{ppm} \mathrm{N}$ was close to equilibrium with the host magma, then the $\mathrm{N}$ concentration of the magma should have been around $10 \mathrm{ppm}$, which leads to $0.2,0.4$ and $2 \mathrm{ppm} \mathrm{N}$ for olivine, clinopyroxene and amphibole, respectively. These model concentrations are larger than the measured concentrations of $\mathrm{N}$ in olivine $(0.10 \mathrm{ppm}$ in DU24), clinopyroxene $(0.12 \mathrm{ppm}$ in DU24 and $0.23 \mathrm{ppm}$ in MM13) and amphibole (0.64 ppm in MM13), suggesting that $\mathrm{N}$ uptake from the host magma would have also occurred for these minerals. The observed $\delta^{15} \mathrm{~N}$ values consequently set lower limits of the original isotopic composition of the minerals in this case, and the olivine with least air-contaminated ${ }^{40} \mathrm{Ar} /{ }^{36} \mathrm{Ar}$ ratio would have best preserved the $\mathrm{N}$ isotopic composition of the time of wehrlite DU24 formation $\left(\delta^{15} \mathrm{~N}=+8 \%\right.$ ). 
The negative correlation between ${ }^{40} \mathrm{Ar} /{ }^{36} \mathrm{Ar}$ ratio and $\delta^{15} \mathrm{~N}$ values among minerals from MM13 may be due to a $\mathrm{N}$ isotopic composition of the host magma at Meerfelder Maar different from that of the wehrlite discussed above (Dreis Weiler). Alternatively, it could also indicate that this sample was heterogeneous for its $\mathrm{N}$ isotopic composition. In relation to this, we note that this sample had a complex history of partial melting, and experienced two different metasomatism events. Olivine might be residual after partial melting whereas amphibole and clinopyroxene were newly formed during fluid-triggered metastomatism. These phases might have subsequently experienced partial exchange of elements with another, more recent recent metasomatic fluid.

The interpretation would have been much easier if the $\mathrm{N}$ concentration and isotopic composition of the host magma would have been known, and this study demonstrates the necessity to consider both the host magma and phenocryst phases in future $\mathrm{N}$ studies of peridotite xenoliths.

\subsubsection{Nitrogen isotope fractionation during other geological processes}

The large isotopic effects observed among co-genetic mineral phases warn against oversimplified interpretations of $\mathrm{N}$ isotopic variations as source signatures, and demonstrate the need to take into account isotopic fractionation of light elements during magmatic processes such as partial melting (Burnard, 2004), crystallization (Teng et al., 2008) and kinetic isotope exchanges during entrainment (Deloule et al., 1991; Peslier and Luhr, 2006; Jeffcoate et al., 2006). Furthermore, different metasomatic pulses could involve different batches of a single melt having evolved through crystal fractionation and/or interaction with other minerals in the mantle (Navon and Stolper, 1987), potentially involving the diffusive exchange. Such process could create a short-term mantle heterogeneity that would probably be homogenized by diffusive and convective mixing with time. 
The possibility of kinetic isotopic fractionation also leads to other possibilities for negative $\delta^{15} \mathrm{~N}$ values observed in fluids from convective mantle. Melt extraction process of MORB (e.g. Burnard, 2004) could be selectively extracting lighter $\mathrm{N}$ and thereby showing lower $\delta^{15} \mathrm{~N}$ value than the actual reservoir. Other sources of magmas such as the subducting slab could also have selectively released light $\mathrm{N}$, mixing into the MORB source (Marty and Dauphas, 2003). The $\mathrm{N}$ isotopic composition of mantle-derived rocks is an integrated result of the geochemical source as well as the geological history, and the effects of these processes on $\mathrm{N}$ isotopic composition are open to exploration.

\subsection{The behavior of $N$ during geological processes}

\subsubsection{Distribution of $N$ in peridotite xenoliths}

As mentioned in subsection 4.2.2, the amounts of Ar extracted by both crushing and heating methods are comparable, indicating that most $\mathrm{Ar}$ resides in fluid inclusion. Conversely, $\mathrm{N}$ extracted by heating extraction by far exceeds that by crushing. Although the $\mathrm{N}$ extraction by crushing may not be complete, the fraction of $\mathrm{N}$ in fluid inclusions can be estimated by assuming that all ${ }^{40} \mathrm{Ar}$ released from fluid inclusion with a mantle $\mathrm{N}_{2}{ }^{40} \mathrm{Ar}$ ratio of $100 \pm 50$ (Marty and Dauphas, 2003). Although crushing of all samples released volatile elements with mantle fluid-like $\mathrm{N}_{2} /{ }^{40} \mathrm{Ar}$ ratios, most heating runs have $\mathrm{N}_{2} /{ }^{40} \mathrm{Ar}>1000$, indicating that $\mathrm{N}$ in peridotites is not only trapped in fluid inclusions, contrary to radiogenic Ar. Similarly high $\mathrm{N}_{2} /{ }^{40} \mathrm{Ar}$ in bulk MORB glasses compared to MORB vesicles were attributed to contamination of melt/glass by organic $\mathrm{N}$ from sediments or altered oceanic crust into the magma, or after eruption through biological alteration (Marty et al, 1995). By analogy, the host magma could have been contaminated by superficial $N$, and interaction of peridotite xenoliths with the magma could account for the observed high $\mathrm{N}_{2} /{ }^{40} \mathrm{Ar}-1$ low ${ }^{40} \mathrm{Ar} /{ }^{36} \mathrm{Ar}$ endmember seen in less refractory minerals. Indeed, the $\mathrm{N}$ isotopic composition of phlogopites 
suggests that such superficial contamination is possible through the host magma, and a part of this enrichment could be attributed to the late addition.

However, elevated $\mathrm{N}_{2} /{ }^{40} \mathrm{Ar}$ ratios are also observed for refractory minerals, e.g. olivine. The higher $\mathrm{N}_{2} /{ }^{40} \mathrm{Ar}$ ratios of minerals relative to that of the fluid phase could therefore be due either to (i) more compatible behavior of $\mathrm{N}_{2}$ in minerals than Ar, or to (ii) the occurrence of another N-bearing phase more compatible in silicates than $\mathrm{N}_{2}$. K-bearing phases such as phlogopite and amphibole show strong enrichments in $\mathrm{N}$ compared to other minerals (Table 4). This is consistent with the $\mathrm{K}^{+}-\mathrm{NH}_{4}{ }^{+}$substitution in $\mathrm{K}$-bearing minerals in peridotites (Andersen et al., 1995). The $\mathrm{K}^{+}-\mathrm{NH}_{4}{ }^{+}$substitution inferred for phlogopite requires $\mathrm{NH}_{4}{ }^{+}$to be stable in the melt that crystallized phlogopite and/or in the host magma, hydrous basanite, that interacted with this phase. If this statement is valid for silicate melt in general, it may also help explaining the $\mathrm{N}$ enrichment in other crystallized silicate phases such as olivine.

\subsubsection{Perspectives on $N$ in the mantle}

Speciation of $\mathrm{N}$ in the mantle under conditions relevant to this reservoir has long been assumed to be $\mathrm{N}_{2}$. Thermodynamic calculations indicate that $\mathrm{NH}_{3}$ cannot be a major phase in the geological environment (e.g. Giggenbach, 1987; Haefner et al., 2002). In addition, there are a few lines of evidence that $\mathrm{N}$ behaves similarly to noble gases in nature (Marty, 1995) and in laboratory experiments (unless $\mathrm{f}_{\mathrm{O} 2}<\mathrm{IW}-1.3$ buffer: Libourel et al., 2003; Miyazaki et al., 2004, which is unlikely for terrestrial magmas). However, abundant $\mathrm{N}$ in granite (Boyd et al., 1993) and the existence of $\mathrm{NH}_{4}{ }^{+}$-bearing minerals at $\mathrm{f}_{\mathrm{O} 2}$ around the QMF buffer (Juster et al., 1987) underlines the importance of $\mathrm{NH}_{4}{ }^{+}$in fluids and magmas. From studies of fluid inclusions in mantle peridotites, Andersen and Neumann (2001) suggested that a significant fraction of $\mathrm{N}$ could reside in mantle minerals as ammonium. Recently, experimental studies on $\mathrm{N}$ in silicate melt reported (i) interaction of $\mathrm{N}$ with the silicate melt forming $\mathrm{N}-\mathrm{O}$ bond (Roskosz et al., 2006), and (ii) formation of ammonium complexes in the presence of water 
(Mysen et al., 2006). Haefner et al. (2002) observed the presence of $\mathrm{NH}_{3}$ in water-bearing silicate system at low $\mathrm{f}_{\mathrm{O} 2}$ with abundant $\mathrm{N}$. The effect of adding water and iron on $\mathrm{N}$ behavior in silicate melts certainly deserves more experimental work.

If $\mathrm{N}$ is proven to abundantly occur in the mantle in other speciation than molecular $\mathrm{N}$, it would become necessary to consider that the concentration of $\mathrm{N}$ in the mantle might be higher than previous estimates based on model Ar concentrations of the mantle and $\mathrm{N}_{2} / \mathrm{Ar}$ ratios of fluid inclusions $(0.27$ and $2.7 \mathrm{ppm}$ for depleted and undepleted mantle: Tolstikhin and Marty, 1998). The observed N concentrations of bulk peridotite xenoliths are however close to the lower end of the estimated values. Furthermore, observed radiogenic ${ }^{40} \mathrm{Ar}$ concentrations of bulk peridotite xenoliths $\left(0.14-5.4 \times 10^{-12} \mathrm{~mol} / \mathrm{g}\right)$ are more than an order of magnitude lower than the modeled one $\left(8 \times 10^{-11} \mathrm{~mol} / \mathrm{g}\right.$ : Tolastikhin and Marty, 1998). This suggests that a significant fraction of mantle-derived fluid phase might have been lost during the entrainment of the peridotite xenoliths probably due to decrepitation of fluid inclusions. The impact of $\mathrm{N}_{2} / \mathrm{Ar}$ variation observed in peridotite xenoliths on the mantle $\mathrm{N}$ budget therefore depends on the degree of this loss and the applicability of the estimated radiogenic ${ }^{40} \mathrm{Ar}$ concentration to this subcontinental mantle region. Provided that refractory minerals did not gain significant fraction of $\mathrm{N}$ from the host magma, 0.1-0.3 ppm would be a reasonable lower limit of $\mathrm{N}$ concentration for the source regions of these peridotite xenoliths.

Finally, the near-constancy of the $\mathrm{N}_{2} /{ }^{40} \mathrm{Ar}$ ratio in mantle-derived fluids from different ridge locations and volcanic environments (Marty, 1995; Dauphas and Marty, 2003; et al., 2009) appears to favor a $\mathrm{N}_{2}$-dominated mantle. In case $\mathrm{N}$ is more compatible than $\mathrm{Ar}$ in the mantle, such observation could be explained by a natural buffering. For instance, $\mathrm{N}$ in excess of the constant $\mathrm{N}_{2} /{ }^{40} \mathrm{Ar}$ ratio could be supplied with water and produce other N-bearing species such as ammonium complexes (Mysen et al., 2006). Alternatively, the higher than MORBs $\mathrm{N}_{2} /{ }^{40} \mathrm{Ar}$ ratios may reflect differences in residence time of volatile elements in the 
sampled reservoirs since the denominator of the ratio, radiogenic ${ }^{40} \mathrm{Ar}$, increases with time (Marty and Dauphas, 2003). Volcanic gases (Fischer et al., 2009) and vesicles of oceanic basalts (Marty, 1995; Marty and Dauphas, 2003) would sample the convective mantle, for which trace element residence time is of the order of $\sim 1$ Ga or more (e.g., Galer and O'Nions 1985), whereas mantle xenoliths from subduction zone (Matsumoto et al., 2002) had higher $\mathrm{N}_{2} /{ }^{40} \mathrm{Ar}$ ratios and had been metasomatized recently.

\subsubsection{Remarks on $N$ recycling}

Nitrogen and $\mathrm{Rb}$ concentrations in bulk rock and minerals from Eifel are well correlated (Fig. 7), suggesting that $\mathrm{N}$ has a geochemical behavior similar to that of alkali elements (e.g., $\mathrm{Rb}$ and $\mathrm{K}$ ) during processes relevant to the genesis of the analyzed xenoliths. As mentioned above, magmatism and metasomatism of this region are probably related to ancient subduction. The $\mathrm{N} / \mathrm{Rb}$ ratios of most peridotite xenoliths are below 0.21 . These values are the upper limit since some $\mathrm{N}$ uptake from the host magma is anticipated, but are significantly lower than those of subducting sediments (Typically 3-6: e.g. Busigny et al., 2003; Sadofsky and Bebout, 2003). The lower N/Rb ratios in peridotite xenoliths relative to that of subducting metasediments indicate that either (i) the contribution of these elements from the subducted plate did not affect that of the regional mantle, or (ii) $\mathrm{N}$ is preferentially lost at the subduction zone and thus $\mathrm{N}$ is not as efficiently recycled as $\mathrm{Rb}$. The flux of $\mathrm{N}$ from subduction zones is estimated to be $\sim 2.0 \times 10^{10} \mathrm{~mol} / \mathrm{yr}$ (Hilton et al., 2002). The corresponding flux of $\mathrm{Rb}$ can be deduced from the lava production rate at arcs and the concentrations of $\mathrm{Rb}$ (10 ppm for volcanism and 85 ppm for plutonism; Plank and Langmuir, 1993; Atherton and Petford, 1996). (Crisp 1984) estimated that $0.5 \mathrm{~km}^{3} / \mathrm{yr}$ of volcanic rocks and $2.8-8 \mathrm{~km}^{3} / \mathrm{yr}$ of plutonic rocks are produced in subduction zones. These numbers lead to $\mathrm{N} / \mathrm{Rb}$ ratios of $0.3-0.9$, comparable to those of peridotite xenoliths from Eifel. The N/Rb ratio 
of flux from subduction zones appears comparable to that of peridotite xenoliths associated to ancient subduction, but significantly lower than that of subducting sediments. This difference implies that $\mathrm{N}$ is significantly lost before reaching the mantle in forearc region.

\section{Conclusion}

Nitrogen isotopic compositions of peridotites xenoliths, both bulk rocks and mineral separates, were analyzed together with their Ar isotopic compositions by stepwise combustion followed by melting, using a platinum crucible in order to avoid analytical biases. Nitrogen isotope signatures of bulk peridotite xenoliths could have been altered by various analytical biases and/or natural secondary effects including various surface contaminations, and fractionation processes during pre-treatments, kinetic isotopic fractionation during gas extraction, and interactions with host magmas through diffusive exchange.

The concentrations of $\mathrm{N}$ (between 7.6 and $25.7 \mathrm{ppm}$ ) are high in phlogopites, whereas those of bulk peridotite xenoliths are 0.1-0.8 ppm. Nitrogen enrichment in phlogopite suggests the occurrence of $\mathrm{NH}_{4}^{+}$in hydrous basanite magma and $\mathrm{K}^{+}-\mathrm{NH}_{4}{ }^{+}$substitution in phlogopite. $\mathrm{N}_{2} /{ }^{40} \mathrm{Ar}$ ratios of minerals and bulk xenoltihs obtained by heating extraction are much higher than the $\mathrm{N}_{2} /{ }^{40} \mathrm{Ar}$ ratios observed in MORB and OIB vesicles, which may be related to the occurrence of $\mathrm{NH}_{4}^{+}$. The correlation between $\mathrm{Rb}$ and $\mathrm{N}$ concentrations of samples from Eifel reinforces the case of ammonium as the main $\mathrm{N}$ species during the genesis of these xenoliths. Their $\mathrm{N} / \mathrm{Rb}$ ratios significantly lower than those of fluxes at subduction zones suggest significant $\mathrm{N}$ loss in fore-arc region.

\section{Acknowledgements}

We thank Laurent Tissandier, Mathieu Roskoz and Guy Libourel for advice and help on the analytical method developments. We are grateful to Raphaël Pik and Ken Farley for 
fruitful discussions. Laurent Zimmermann is deeply acknowledged for help during experiments. We wish to thank Pierre Cartigny, Toby Fischer, and an anonymous reviewer for their careful reviews. R. Y. thanks Nicolas Dauphas for persistent encouragement. This study was supported by a grant from Interieur de la Terre program, Institut National des Sciences de l'Univers. This is CRPG contribution 1992. 


\section{References}

Adam, J., Green, T. H., and Sie, S. H. (1993) Proton microprobe determined partitioning of Rb, Sr, $\mathrm{Ba}, \mathrm{Y}, \mathrm{Zr}, \mathrm{Nb}$ and $\mathrm{Ta}$ between experimentally produced amphiboles and silicate melts with variable F content. Chem. Geol. 109, 29-49.

Andersen T., Burke E. A. J., and Neumann E.-R. (1995) Nitrogen-rich fluid in the upper mantle: fluid inclusions in spinel dunite form Lanzarote, Canary Islands. Contrib. Mineral. Petrol. 120, 20-28.

Andersen T. and Neumann E.-R. (2001) Fluid inclusions in mantle xenoliths. Lithos 55, 301320.

Atherton, M. P. and Petford, N., 1996. Plutonism and the growth of Andean Crust at $9^{\circ}$ S from 100 to 3 Ma. J. South Amer. Earth Sci. 9, 1-9.

Baker J., Chazot G., Menzies M., and Thirlwall M. (1998) Metasomatism of the shallow mantle beneath Yemen by the Afar plume-implications for mantle plumes, flood volcanism, and intraplate volcanism. Geology 26(5), 431-434.

Bebout G. E. and Fogel M. L. (1992) Nitrogen-isotope compositions of metasedimentary rocks in the Catalina Schist, California: Implications for metamorphic devolatilization history. Geochim. Cosmochim. Acta 56(7), 2839-2849.

Boyd S. R., Hall A., and Pillinger C. T. (1993) The measurement of $\delta^{15} \mathrm{~N}$ in crustal rocks by static vacuum mass spectrometry: Application to the origin of the ammonium in the Cornubian batholith, southwest England. Geochim. Cosmochim. Acta 57, 1339-1347.

Boyd S. R., Mattey D. P., Pillinger C. T., Milledge H. J., Mendelssohn M., and Seal M. (1987) Multiple growth events during diamond genesis: an integrated study of carbon and nitrogen isotopis and nitrogen aggregation state in coated stones. Earth Planet. Sci. Lett. 86, 341-353.

Burnard P. (2004) Diffusive fractionation of noble gases and helium isotopes during mantle melting. Earth Planet. Sci. Lett. 220, 287-295.

Busigny V., Cartigny P., Philippot P., Ader M., and Javoy M. (2003) Massive recycling of nitrogen and other fluid-mobile elements $(\mathrm{K}, \mathrm{Rb}, \mathrm{Cs}, \mathrm{H})$ in a cold slab environment: evidence from HP to UHP oceanic metasediments of the Schistes Lustres nappe (western Alps, Europe). Earth Planet. Sci. Lett. 215, 27-42.

Cartigny P., Boyd S. R., Harris J. W., and Javoy M. (1997) Nitrogen isotopes in peridotitic diamonds from Fuxian, China: the mantle signature. Terra Nova 9(4), 175-179.

Chazot, G., Menzies, M.A. and Harte, B., (1996a) Silicate glasses in spinel lherzolites from Yemen: Origin and chemical composition. Chem. Geol. 134: 159-179.

Chazot G., Menzies M., and Harte B. (1996b) Silicate glasses in spinel lherzolites from Yemen: origin and chemical composition. Chem. Geol. 134, 159-179.

Chazot G., Lowry D., Menzies M., and Mattey D. (1997) Oxygen isotopic composition of 
hydrous and anhydrous mantle peridotites. Geochim. Cosmochim. Acta 61(1), 161-169.

Crank, J., 1975. The Mathematics of Diffusion, 2nd ed. Oxford University Press.

Crisp, J. A. (1984) The rate of magma emplacement and volcanic output. J. Volcanol. Geotherm. Res. 20: 177-211.

Dauphas N. and Marty B. (1999) Heavy Nitrogen in Carbonatites of Kola Peninsula: A Possible Signature of the Deep Mantle. Science 286, 2488-2490.

Deloule E., Albarede F., and Sheppard S. M. F. (1991) Hydrogen isotope heterogeneities in the mantle from ion probe analysis of amphiboles from ultramafic rocks. Earth Planet. Sci. Lett. 105, 543-553.

Dunai, T. J. and Baur, H. (1995) Helium, neon, argon systematics of the European subcontinental mantle: Implications for its geochemical evolution. Geochim. Cosmochim. Acta 59, 27672783.

Farley, K. A. and Craig, H. (1994) Atmospheric argon contamination of ocean island basalt olivin phenocrysts. Geochim. Cosmochim. Acta 58, 2509-2517.

Fischer, T. P., Burnard, P., Marty, B., Hilton, D. R., Furi, E., Palhol, F., Sharp, Z. D., and Mangasini, F. (2009) Upper-mantle volatile chemistry at Oldonyo Lengai volcano and the origin of carbonatites. Nature In press.

Fischer T. P., Hilton D. R., Zimmer M. M., Shaw A. M., Sharp Z. D., and Walker J. A. (2002) Subduction and Recycling of Nitrogen Along the Central American Margin. Science 297, 1154-1157.

Fischer, T. P., Takahata, N., Sano, Y., Sumino, H., and Hilton, D. R. (2005) Nitrogen isotopes of the mantle: Insights from mineral separates. Geophys. Res. Lett. 32, L11305.

Gaber L. J., Foland K. A., and Corbato C. E. (1988) On the significance of argon release from biotite and amphibole during ${ }^{40} \mathrm{Ar} /{ }^{39} \mathrm{Ar}$ vacuum heating. Geochim. Cosmochim. Acta 52, 2457-2465.

Galer, S. J. G. and R. K. O'Nions (1985). "Residence time of thorium, uranium and lead in the mantle with implications for mantle convection. Nature 316(6031): 778-782.

Giggenbach, W.F. (1987) Redox processes governing the chemistry of fumarolic gas discharges from White Island, New Zealand. Appl. Geochem. 2, 143-161.

Haefner A., Aranovich L. Y., Connolly J. A. D., and Ulmer P. (2002) $\mathrm{H}_{2} \mathrm{O}$ activity in $\mathrm{H}_{2} \mathrm{O}-\mathrm{N}_{2}$ fluids at high pressure and temperature measured by the brucite-periclase equilibrium. Amer. Mineral. 87, 822-828.

Haendel D., Muhle K., Nitzsche H.-M., Stiehl G., and Wand U. (1986) Isotopic variations of the fixed nitrogen in metamorphic rocks. Geochim. Cosmochim. Acta 50, 749-758.

Hilton D. R., Fischer T. P., and Marty B. (2002) Noble Gases and Volatile Recycling at Subduction Zones. In Noble Gas in Geochemistry and Cosmochemistry (Eds. D.P. 
Porcelli, C.J. Ballentine, and R. Wieler) Mineral. Soc. Amer., Washington D.C.. pp. 319-370.

Honma H. and Itihara Y. (1981) Distribution of ammonium in minerals of metamorphic and granitic rocks. Geochim. Cosmochim. Acta 45, 983-988.

Huang L. (1997) The abundance and isotopic composition of nitrogen in mantle xenoliths: Implications for mantle-atmosphere evolution. PhD Thesis, University of Chicago.

Irving, A. J. and Frey, F. A. (1984) Trace element abundances in megacrysts and their host basalts: Constraints on partition coefficients and megacryst genesis. Geochim. Cosmochim. Acta $\mathbf{4 8}$, 1201-1221.

Itihara Y. and Honma H. (1979) Ammonium in biotite from metamorphic and granitic rocks of Japan. Geochim. Cosmochim. Acta 43, 503-509.

Javoy M., Pineau F., and Demaiffe D. (1984) Nitrogen and carbon isotopic composition in the diamonds of Mbuji Mayi (Zaire). Earth Planet. Sci. Lett. 68, 399-412.

Javoy M. and Pineau F. (1991) The volatiles record of a "popping" rock from the MidAtlantic Ridge at $14^{\circ} \mathrm{N}$ : chemical and isotopic composition of gas trapped in the vesicles. Earth Planet. Sci. Lett. 107, 598-611.

Jeffcoate A. B., Elliott T., Kasemann S. A., Ionov D., Cooper K., and Brooker R. (2006) Li isotope fractionation in peridotites and mafic melts. Geochim. Cosmochim. Acta 71(1), 202-218.

Juster T. C., Brown P. E., and Bailey S. W. (1987) $\mathrm{NH}_{4}$-bearing illite in very low grade metamorphic rocks associated with coal, northern Pensylvania. Amer. Mineral. 72, $555-565$.

Kelley S. P. and Wartho J.-A. (2000) Rapid kimberlite ascent and the significance of Ar-Ar ages in xenoliths phlogopites. Science 289, 609-611.

LaTourrette, T., Hervig, R. L., and Holloway, J. R. (1995) Trace element partitioning between amphibole, phlogopite, and basanite melt. Earth Planet. Sci. Lett. 135, 13-30.

Lemarchand, F., Villemant, B., and Calas, G. (1987) Trace element distribution coefficients in alkaline series. Geochim. Cosmochim. Acta 51, 1071-1081.

Libourel G., Marty B., and Humbert F. (2003) Nitrogen solubility in basaltic melt. Part I. Effect of oxygen fugasity. Geochim. Cosmochim. Acta 67(21), 4123-4135.

Lloyd F. E. and Bailey D. K. (1975) Light element metasomatism of the continental mantle: the evidence and the consequences. Phys. Chem. Earth 9, 389-416.

Marty B. (1995) Nitrogen content of the mantle inferred from $\mathrm{N}_{2}$-Ar correlation in oceanic basalts. Nature 377, 326-329.

Marty B. and Dauphas N. (2003) The nitrogen record of crust-mantle interaction and mantle convection from Archean to Present. Earth Planet. Sci. Lett. 6515, 1-14. 
Marty B., Lenoble M., and Vassard N. (1995) Nitrogen, helium, and argon in basalt: a static mass spectrometry study. Chem. Geol. 120, 183-195.

Marty B. and Humbert F. (1997) Nitrogen and argon isotopes in oceanic basalts. Earth Planet. Sci. Lett. 152, 101-112.

Marty B. and Zimmermann L. (1999) Volatiles (He, C, N, Ar) in mid-ocean ridge basalts: Assesment of shallow-level fractionation and characterization of source composition. Geochim. Cosmochim. Acta 63(21), 3619-3633.

Mingram B. and Brauer K. (2001) Ammonium concentration and nitrogen isotope composition in metasedimentary rocks from different tectonometamorphic units of the European Variscan Belt. Geochim. Cosmochim. Acta 65(2), 273-287.

Matsumoto, T., Pinti, D. L., Matsuda, J., and Uminjo, S. (2002) Recycled noble gas and nitrogen in the subcontinental lithospheric mantle: Implications from N-He-Ar in fluid incusions of SE Australian xenoliths. Geochem. J. 36, 209-217.

Miyazaki A., Hiyagon H., Sugiura N., Hirose K., and Takahashi E. (2004) Solubilities of nitrogen and noble gases in silicate melts under various oxygen fugasities: Implications for the origin and degassing history of nitrogen and noble gases in the Earth. Geochim. Cosmochim. Acta 68(2), 387-401.

Mohapatra R. K. and Murty S. V. S. (2000) Search for the mantle nitrogen in the ultramafic xenoliths from San Carlos, Arisona. Chem. Geol. 164, 305-320.

Mohapatra R. and Murty S. V. S. (2002) Nitrogen and noble gas isotopes in mafic and ultramafic inclusions in the alkali basalts from Kutch and Reunion - implications for their mantle sources. J. Asian Earth Sci. 20(7), 867-877.

Mohapatra R. K. and Murty S. V. S. (2003) Nitrogen isotopic composition of the MORB mantle: A reevaluation. Geochem. Geophys. Geosyst. 5(1), $2003 \mathrm{GC} 000612$.

Mysen B. O., Roskosz M., and Cody G. D. (2006) The 'not so noble' behaviour of nitrogen in silicate melts at high pressure and temperature. Geochim. Cosmochim. Acta 70(18(S1)), A439.

Navon, O and Stolper, E. (1987) Geochemical consequences of melt percolation: the upper mantle as a chromatographic column. J. Geol. 95, 285-307.

Nishio Y., Ishii T., Gamo T., and Sano Y. (1999) Volatile element isotopic systematics of the Rodrigues Triple Junction Indian Ocean MORB: implications for mantle heterogeneity. Earth Planet. Sci. Lett. 170, 241-253.

Pesler A. H. and Luhr J. F. (2006) Hydrogen loss from olivines in mantle xenoliths from Simcoe (USA) and Mexico: Mafic alkalic magma ascent rates and water budget of the sub-continental lithosphere. Earth Planet. Sci. Lett. 242, 302-319.

Pinti, D. L., Hashizume, K., Orberger, B., Gallien, J.-P., Cloquet, C., and Massault, M. (2007) Biogenic nitrogen and carbon in Fe-Mn-oxyhydroxides from an Archan chert, Marble Bar, Western Australia. Geochem. Geophys. Geosyst. 8, Q02007. 
Plank T. and Langmuir C. H. (1993) Tracing trace elements from sediment input to volcanic output at subduction zones. Nature 362, 739-743.

Raffone, N., Chazot, G., Pin, C., Vannucci, R., and Zanetti, A. (2009) Metasomatism in the Lithospheric Mantle beneath Middle Atlas (Morrocco) and the Origin of Fe- and Mg-rich Wehrlites. J. Petrol. 50, 197-249.

Richard D., Marty B., Chaussidon M., and Arndt N. (1996) Helium Isotopic Evidence for a Lower Mantle Component in Depleted Archean Komatiite. Science 273, 93-95.

Richet P., Bottinga Y., and Javoy M. (1977) A review of hydrogen, carbon, nitrogen, oxygen, sulphur, and chlorine stable isotope fractionation among gaseous molecules. Ann. Rev. Earth Planet. Sci. Lett. 5, 65-110.

Roskosz M., Mysen B. O., and Cody G. D. (2006) Dual speciation of nitrogen in silicate melts at high pressure and temperature: An experimental study. Geochim. Cosmochim. Acta 70, 2902-2918.

Sadofsky S. J. and Bebout G. E. (2003) Record of forearc devolatilization in low-T, high-P/T metasedimentary suites: Significance for models of convergent margin chemical cycling. Geochem. Geophys. Geosyst. 4(4), 9003, doi:10.1029/2002GC000412.

Sadofsky S. J. and Bebout G. E. (2004) Nitrogen geochemistry of subducting sediments: New results from the Izu-Bonin-Mariana margin and insights regarding global nitrogen subduction. Geochem. Geophys. Geosyst. 5(3), Q03I15, doi:10.1029/2003GC000543.

Stosch H.-G. and Seck H. A. (1980) Geochemistry and mineralogy of two spinel peridotite suites from Dreiser Weiher, West Germany. Geochim. Cosmochim. Acta 44, 457-470.

Stosch H.-G. and Lugmair G. W. (1986) Trace element and Sr and Nd isotope geochemistry of peridotite xenoliths from the Eifel (West Germany) and their bearing on the evolution of the subcontinental lithosphere. Earth Planet. Sci. Lett. 80, 281-298.

Teng F.-Z., Dauphas N., and Helz R. T. (2008) Iron Isotope Fractionation During Magmatic Differentiation in Kilauea Iki Lava Lake. Science 320(5883), 1620-1622.

Tolstikhin I. N. and Marty B. (1998) The evolution of terrestrial volatiles: a view from helium, neon, argon and nitrogen isotope modelling. Chem. Geol. 147, 27-52.

Urey H. C. (1947) The thermodynamic properties of isotopic substances. J. Chem. Soc. 1947, 562-581.

Yokochi R., Pik R., Marty B., and Chazot G. (2002) Extension of the Afar Plume Material: He isotope Constraints. Geochim. Cosmochim. Acta 66(S1), A684.

Yokochi R. and Marty B. (2006) Fast chemical and isotopic exchange of nitrogen during reaction with hot molybdenum. Geochem. Geophys. Geosyst. 7(7), $2006 \mathrm{GC} 001253$.

Williams L.B., Ferrell Jr. R.E., Hutcheon I., Bakel A.J., Walsh M.M. and Krouse H.R. (1995) Nitrogen isotope geochemistry of organic matter and minerals during diagenesis and hydrocarbon migration, Geochim. Cosmochim. Acta 59, 765-779. 
Wilson M. and Downes H. (1991) Tertiary-Quarternary Extension-Related Alkaline Magmatism in Western and Central Europe. J. Petrol. 32(4), 811-849.

Witt G. and Seck H. A. (1989) Origin of amphibole in recrystallized and porphyroclastic mantle xenoliths from the Rhenish Massif: implications for the nature of mantle metasomatism. Earth Planet. Sci. Lett. 91, 327-340.

Witt-Eickschen G., Kaminsky W., Kramm U., and Ben H. (1998a) The Nature of Young Vein Metasomatism in the Lithosphere of the West Eifel (Germany): Geochemical and Isotopic Constraints from Composite Mantle Xenoliths from the Meerfelder Maar. $J$. Petrol. 39(1), 155-185.

Witt-Eickschen G. and Kramm U. (1998b) Evidence for the multiple stage evolution of the subcontinental lithospheric mantle beneath the Eifel (Germany) from pyroxenite and composite pyroxene/peridotite xenoliths. Contrib. Mineral. Petrol. 131, 258-272.

Witt-Eickschen G., Seck H. A., and Reys C. (1993) Multiple Enrichment Processes and their Relationships in the Subcrustal Lithosphere Beneath the Eifel (Germany). J. Petrol. 34(1), 1-22.

Witt-Eickschen G., Seck H. A., Mazger K., Eggins S. M., and Altherr R. (2003) Lithospheric Mantle Evolution beneath the Eifel (Germany): Constraints from $\mathrm{Sr}-\mathrm{Nd}-\mathrm{Pb}$ Isotopes and Trace Element Abundances in Spinel Peridotite and Pyroxenite Xenoliths. $J$. Petrol. 44(6), 1077-1095.

Worner G., Zondler A., Staudigel H., and Schmincke H.-U. (1986) Sr, Nd, and Pb isotope geochemistry of Tertiary and Quaternary alkaline volcanics from West Germany. Earth Planet. Sci. Lett. 79, 107-119. 


\section{Figure Captions}

Figure 1: A correlation between $\mathrm{N}_{2} /{ }^{40} \mathrm{Ar}$ and ${ }^{40} \mathrm{Ar} /{ }^{36} \mathrm{Ar}$ ratios among mineral separates of peridotite xenoliths from Yemen by crushing extraction. One end of the correlation points to an unfractionated atmospheric composition shown as an open star.

Figure 2: Nitrogen isotopic composition and release fractions of mineral separates and bulk rock samples. Bars and dots represent $\mathrm{N}$ fraction and $\delta^{15} \mathrm{~N}$, respectively.

Figure 3: Rough positive correlation between the $1 /{ }^{36} \mathrm{Ar}$ concentration and $\mathrm{Ar}$ isotopic composition representing mixing of $\mathrm{Ar}$ in the mineral matrix, in fluid inclusions and from atmospheric contamination. Open and filled symbols represent data by crushing and heating extraction, respectively. Yemen samples are shown as squares, mineral separates of samples from Europe are shown as circle, and pentagons represents bulk rock analysis. Data plotted in this diagram are sum of temperature steps over $>900{ }^{\circ} \mathrm{C}$. Exceptions are described in the text Section 4.2.1 and Table 4.

Figure 4: $\mathrm{N}_{2} /{ }^{40} \mathrm{Ar}-{ }^{40} \mathrm{Ar} /{ }^{36} \mathrm{Ar}$ plot. Symbols are same as Figure 3.

Figure 5: (a) Inverse correlation between $\delta^{15} \mathrm{~N}$ and ${ }^{40} \mathrm{Ar} /{ }^{36} \mathrm{Ar}$ of different phases (clinopyroxene, amphibole and whole rock) from MM13. (b) Correlation between $\delta^{15} \mathrm{~N}$ and ${ }^{40} \mathrm{Ar} /{ }^{36} \mathrm{Ar}$ of different phases (Whole rock, clinopyroxene, olivine and phlogopite) from DU24.

Figure 6: Isotopic evolution path of minerals assuming a diffusive mixing of $\mathrm{N}$ with the host magma. Initial $\delta^{15} \mathrm{~N}$ of the mineral is set as $0 \%$. (a) and (b) show cases of $\mathrm{N}$ uptake into minerals with a fractionation factors of $(18 / 19)^{0.5}$ and $(28 / 29)^{0.25}$, respectively. Arrows indicates the direction of evolution. $\mathrm{X}$-axis is the deviation of $\mathrm{N}$ isotopic composition from the initial $\delta^{15} \mathrm{~N}$ value of the mineral $(=0 \%)$, and $\mathrm{Y}$-axis represents the ratio of the $\mathrm{N}$ concentration in the mineral $\left(\mathrm{C}_{\min , t}\right)$ to the equilibrium $\mathrm{N}$ concentration of the host magma $(\mathrm{C}$ $=\mathrm{C}_{\mathrm{liq}}{ }^{*}$ in the text). (c) and (d) are loss cases with a fractionation factors of $(18 / 19)^{0.5}$ and $(28 / 29)^{0.25}$, respectively. Y-axis represents the ratio of the $\mathrm{N}$ concentration in the mineral $\left(\mathrm{C}_{\min , \mathrm{t}}\right)$ at time $\mathrm{t}$ to time $0\left(\mathrm{C}=\mathrm{C}_{\min , 0}\right)$.

Figure 7: $\mathrm{Rb}$ and $\mathrm{N}$ concentrations of samples from Eifel, showing positive correlation. 
Table Captions

Table 1

Sample list: Sampling locality, mineral assemblage, rock type and geological events related to the samples are listed. For samples from Yemen, (BA8, JK7, JK8), see also Chazot et al. (1997).

Table 2

Selected trace element compositions and $\mathrm{Sr}$ isotopic compositions of bulk rocks and mineral separates from Eifel are listed. Concentrations of trace elements were analyzed by SIMS $3 \mathrm{f}$ for mineral separates and by SARM for bulk rocks. Sr isotopic compositions and concentrations were analyzed by TIMS.

\section{Table 3}

Nitrogen and Ar isotopic composition and concentration of mineral separates from peridotite xenoliths analyzed by vacuum crushing. In the case of phlogopites, only the first step $\left(700^{\circ} \mathrm{C}\right)$ is excluded from the calculation of trapped composition due to its relatively low $\mathrm{N}$ release temperature, which does not significantly affect the total budget.

\section{Table 4}

Nitrogen and Ar isotopic composition and concentration of peridotite xenoliths and their mineral separates analyzed by step-wise combustion. "b.l." represents blank level. 


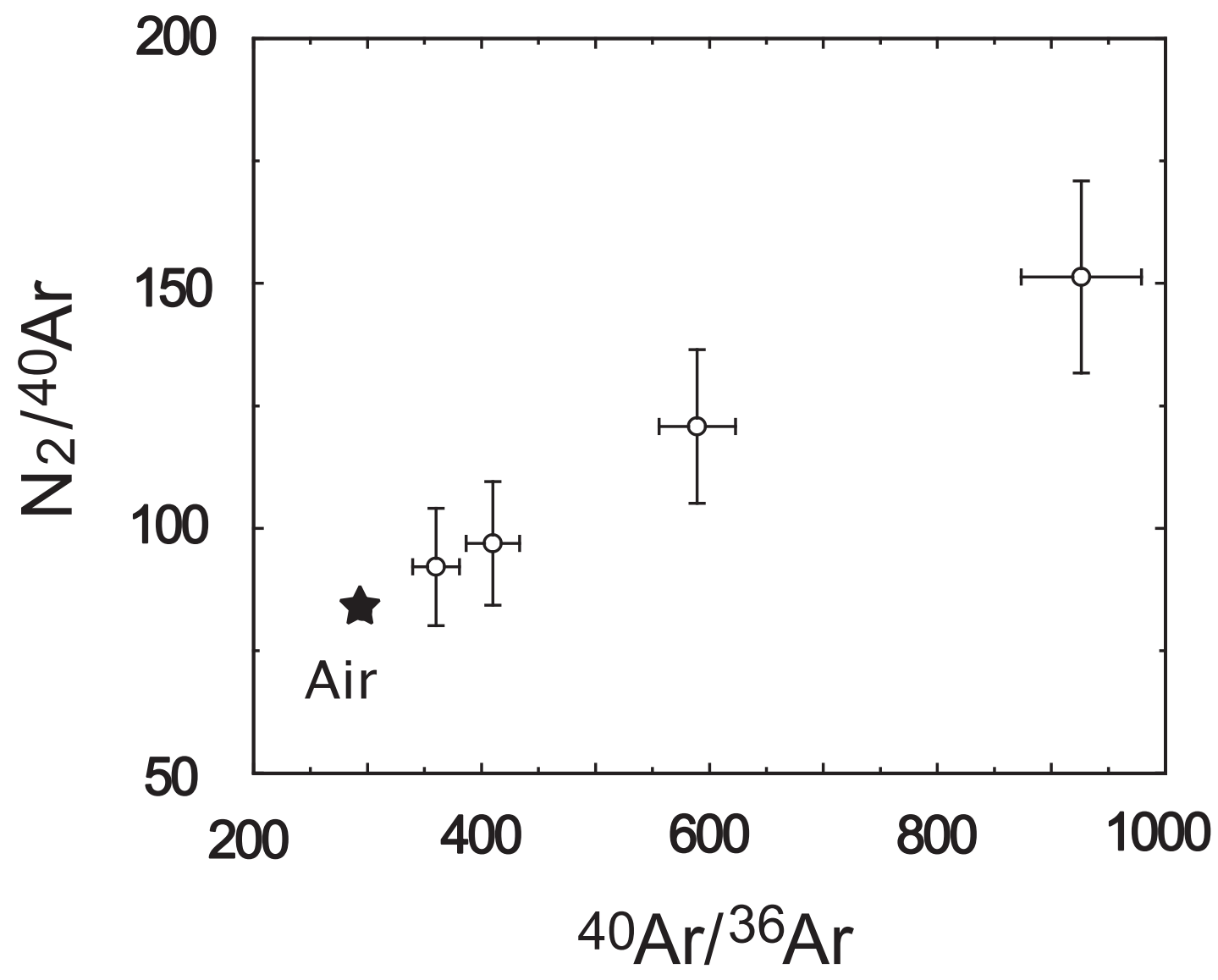

Figure 1 
Fraction
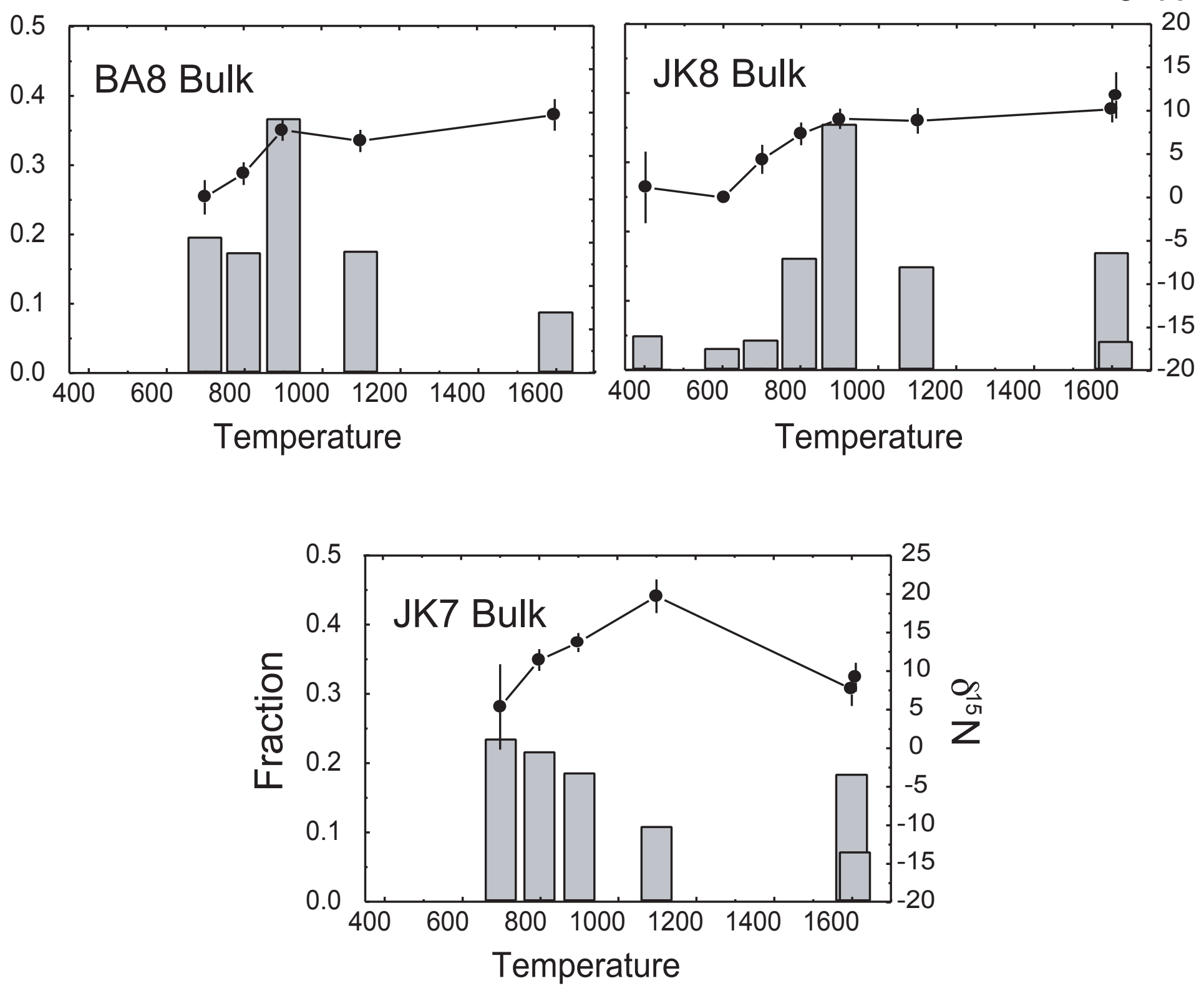

Fraction
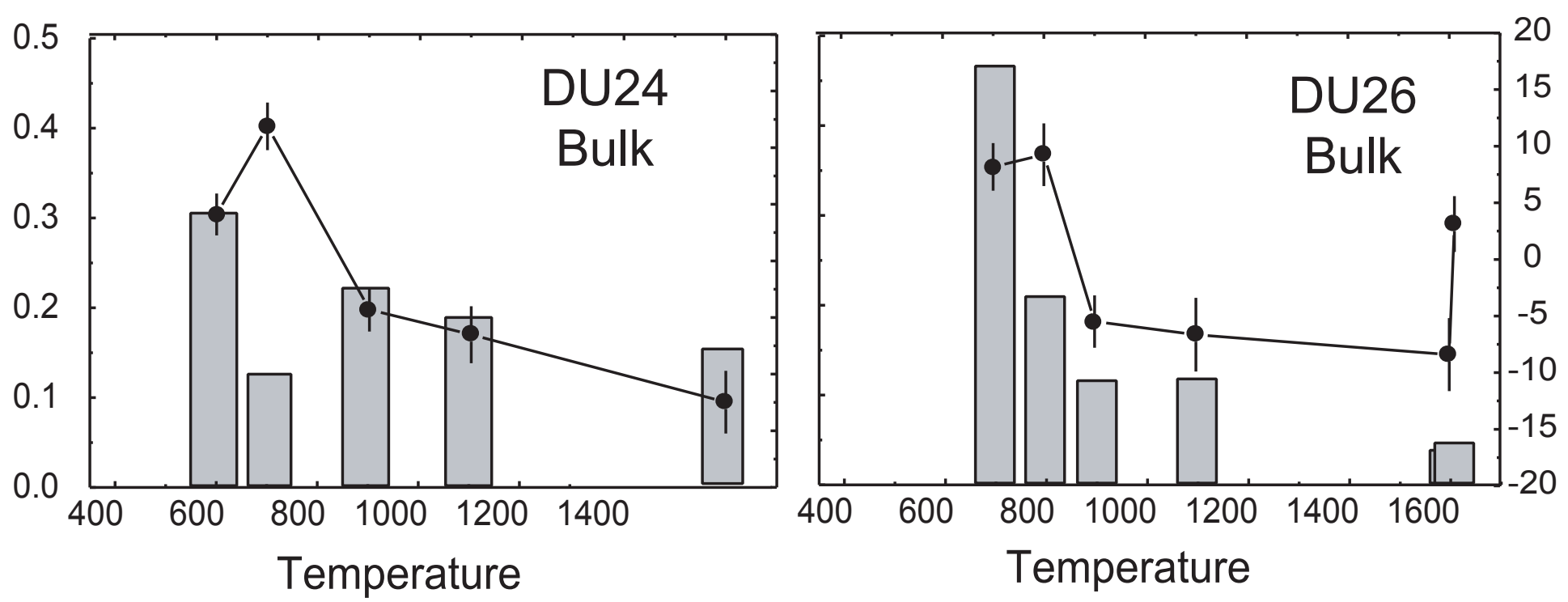

Figure 2-1 
Fraction
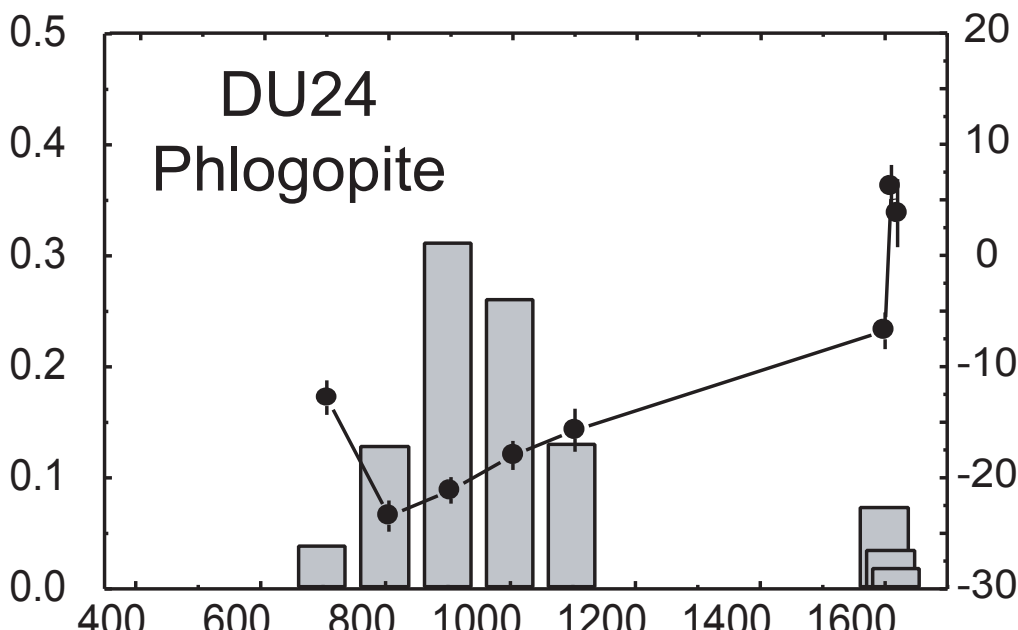

0.5 DU26

0.4 Phlogopite

0.3

0.2

0.1
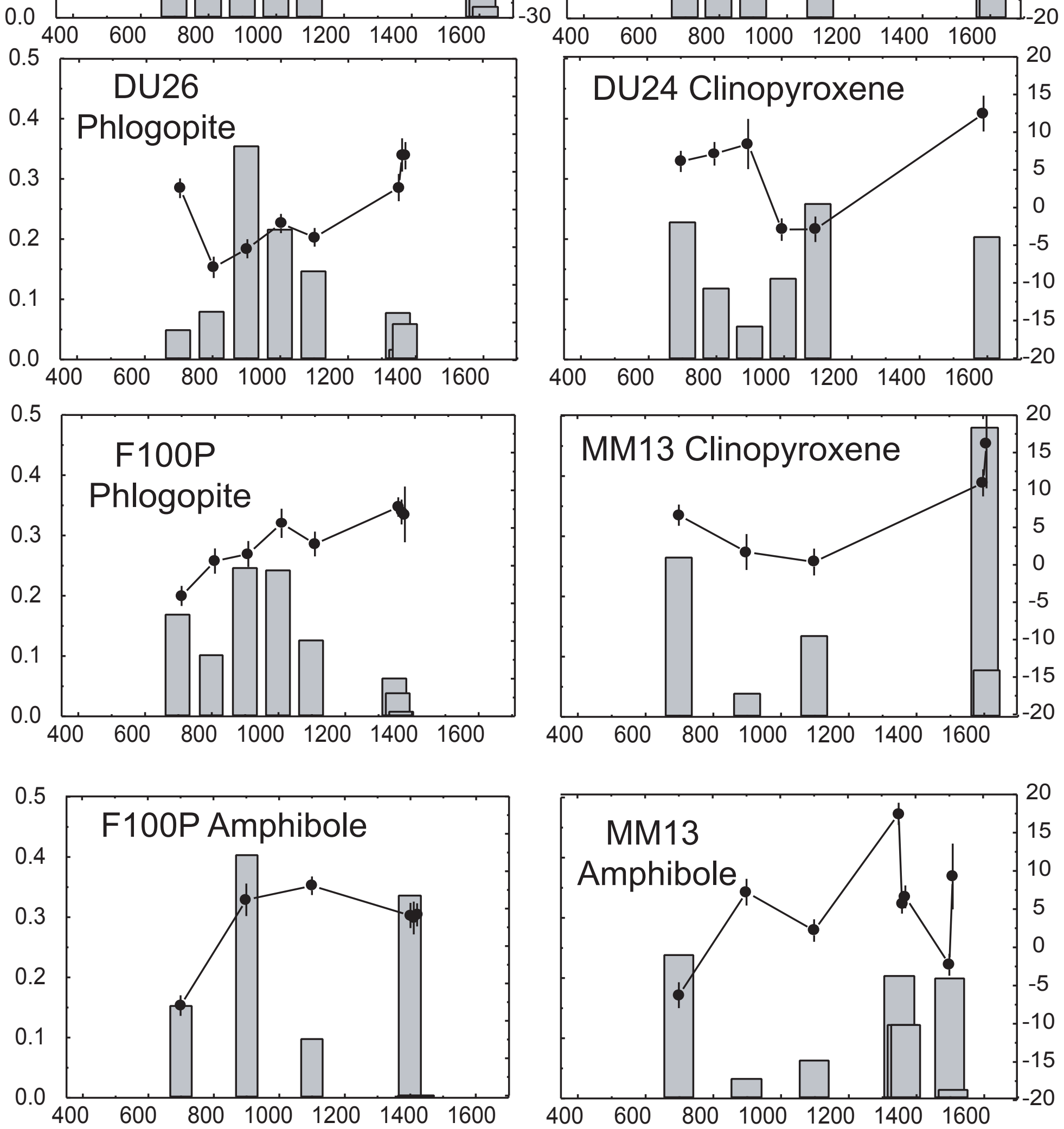
Fraction

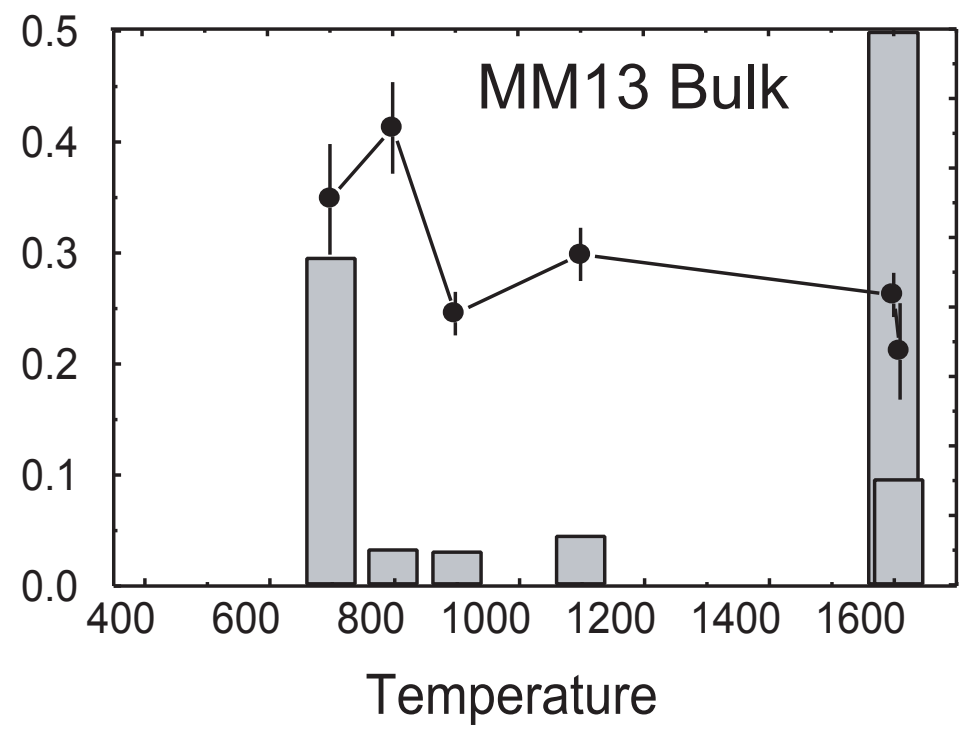

$\square^{5} \mathrm{~N}$

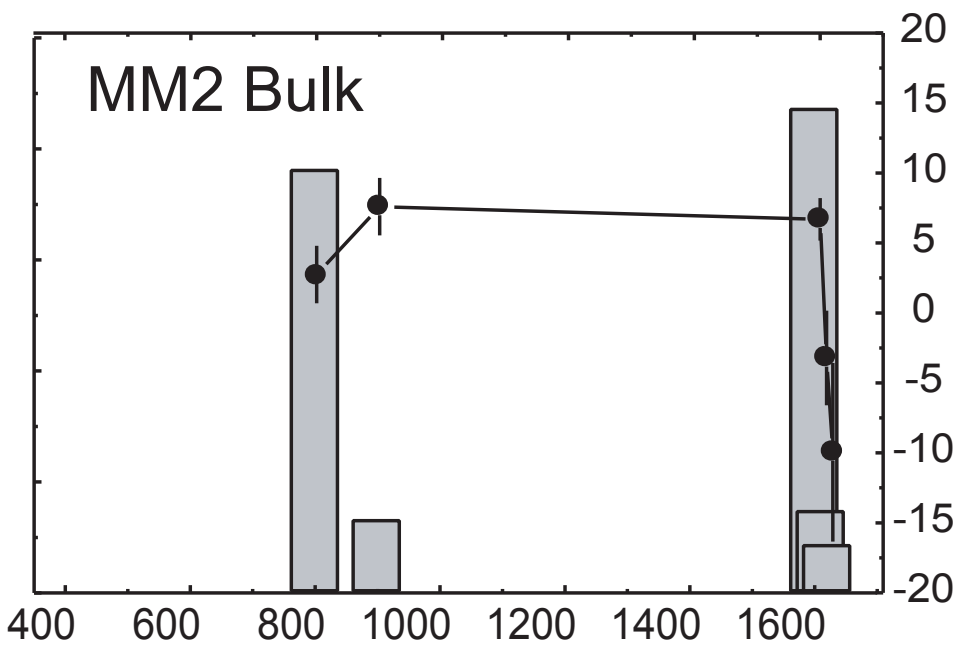

Temperature
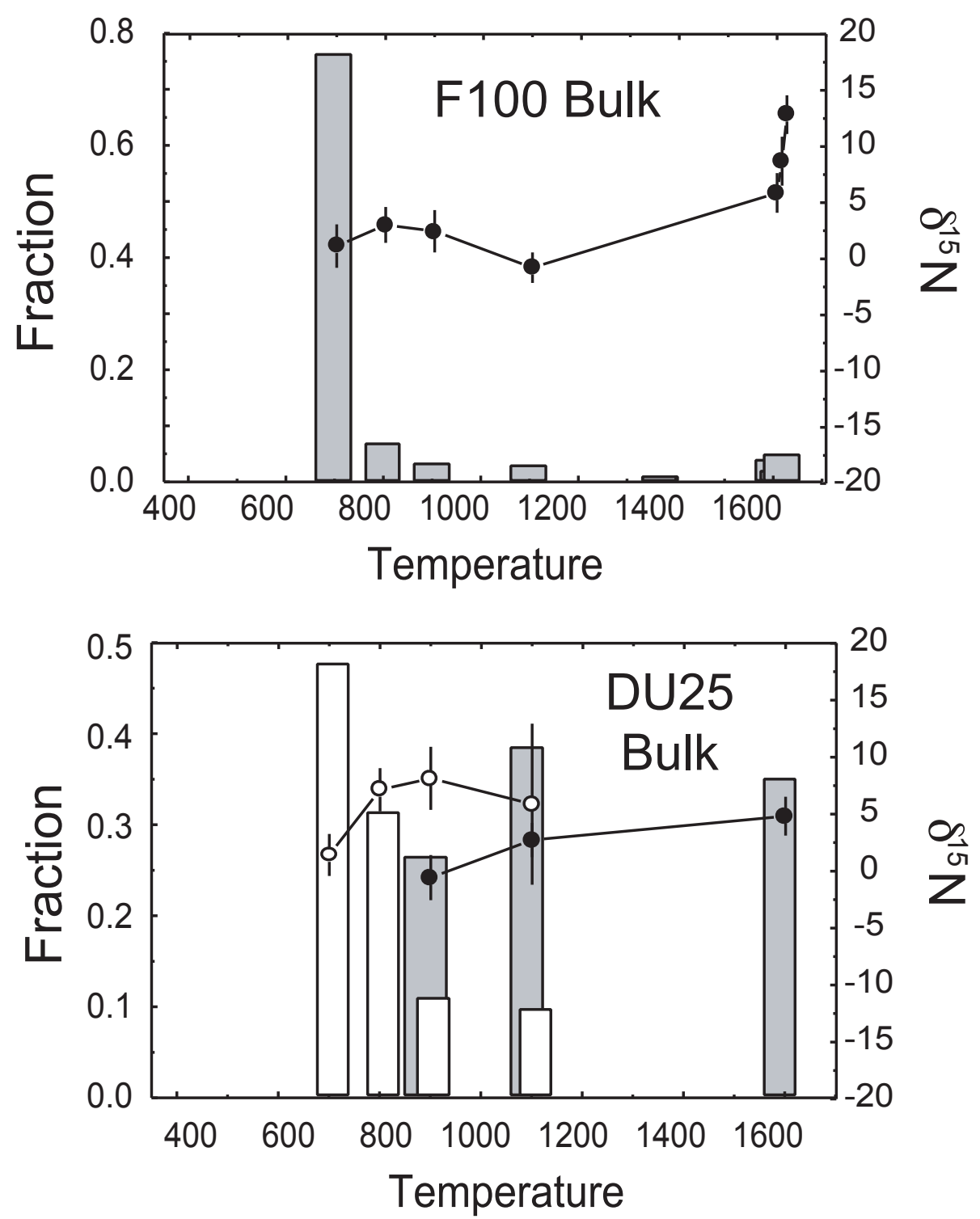

Figure 2-3 


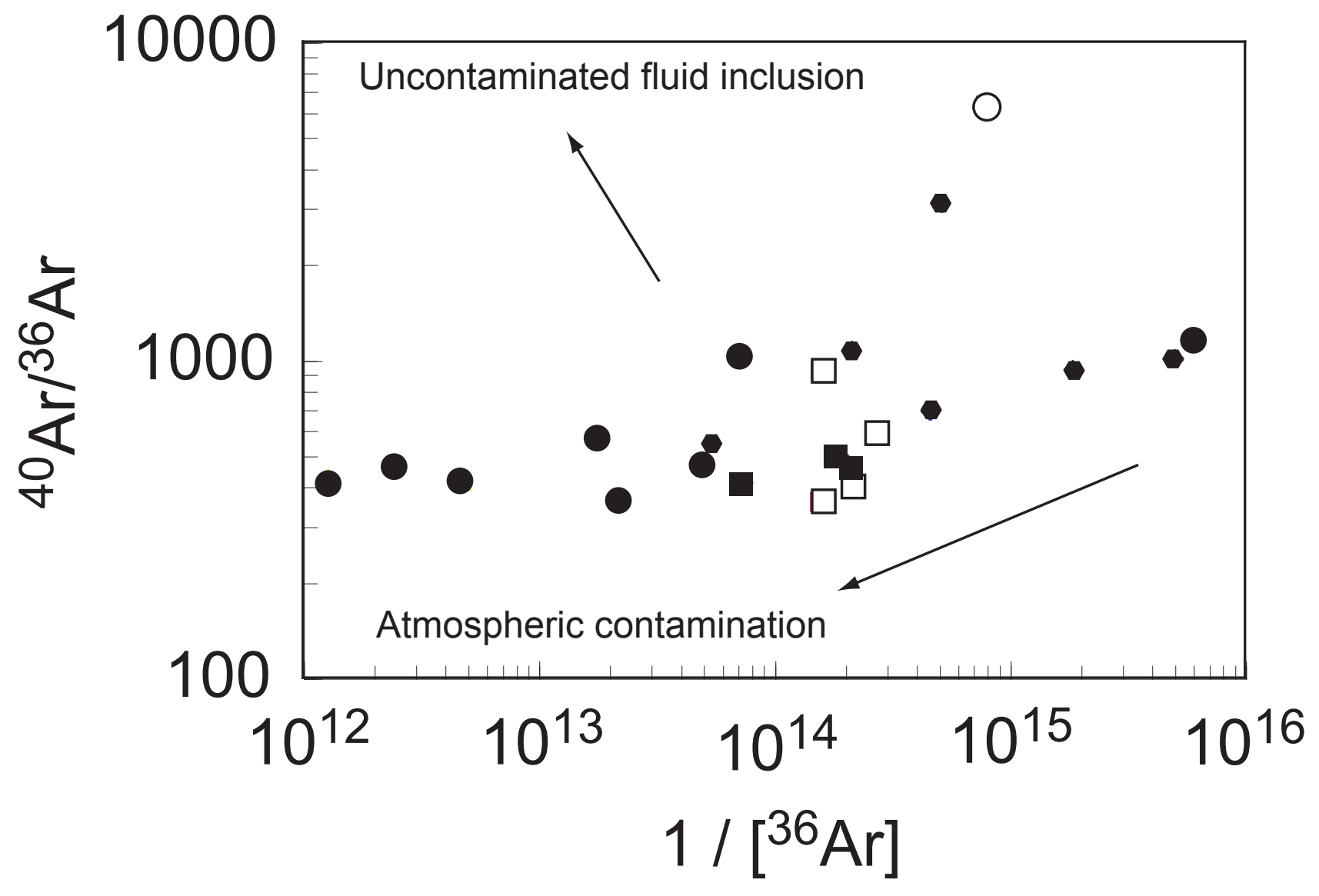

Figure 3 


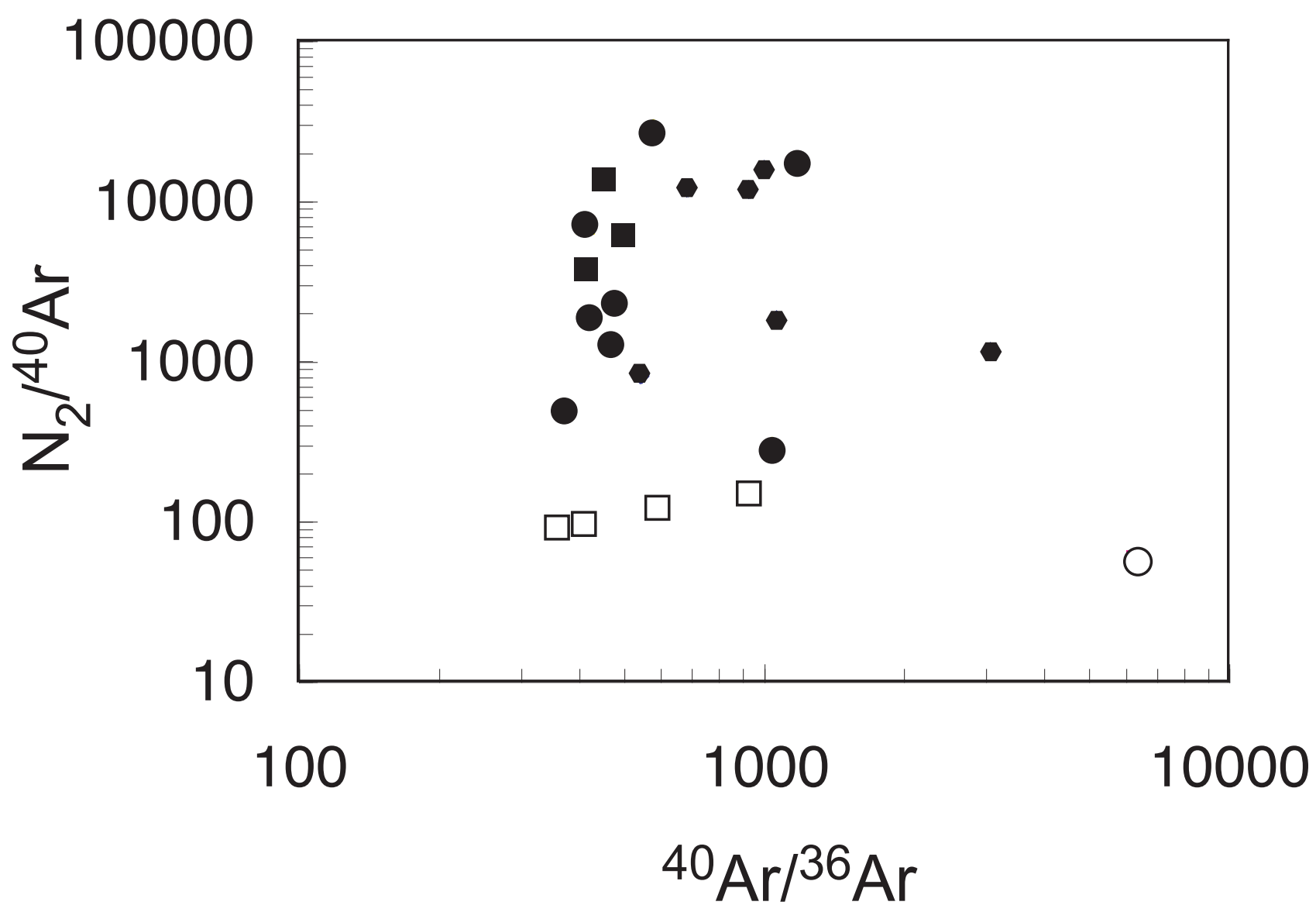

Figure 4 

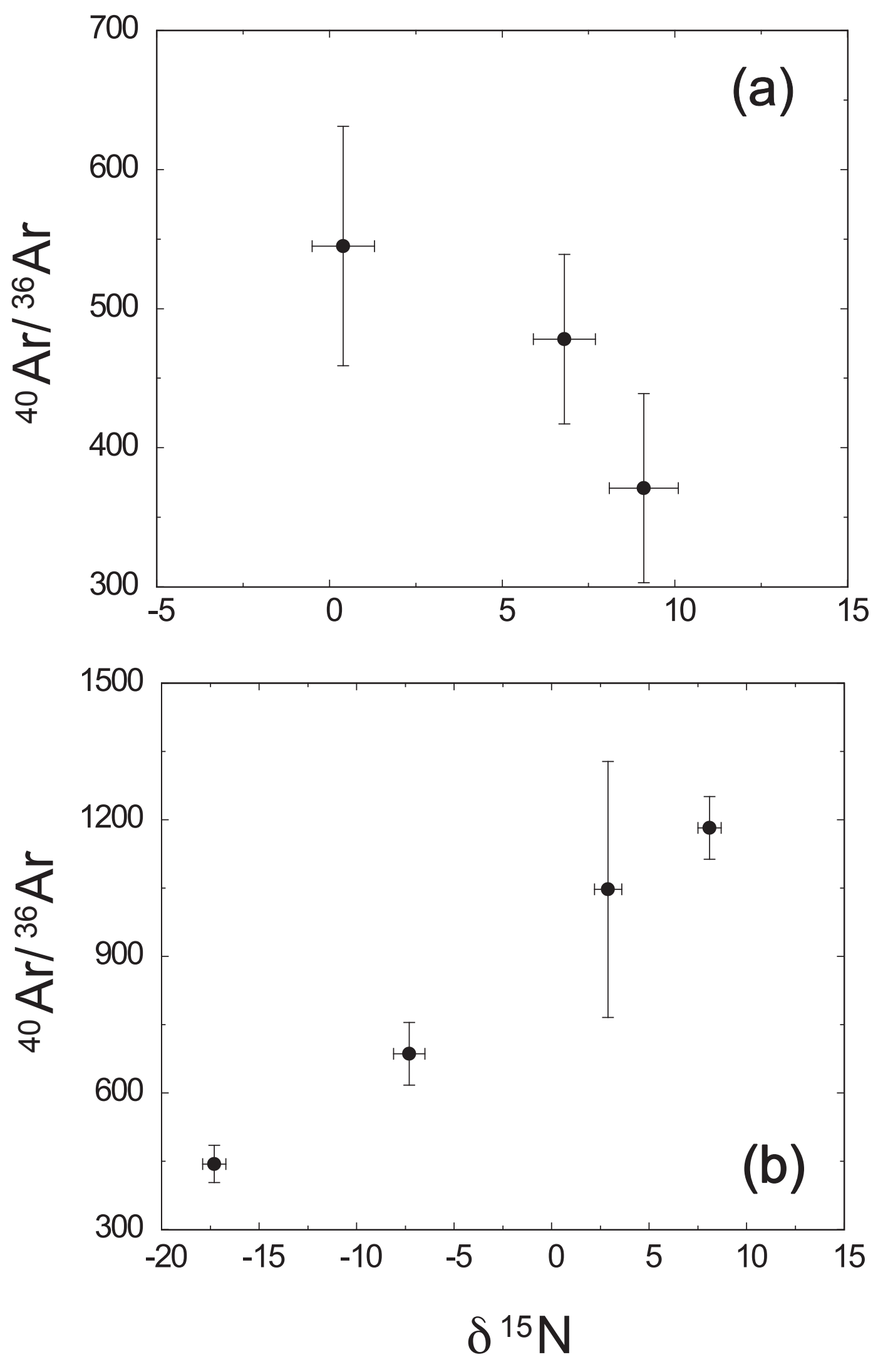

Figure 5 


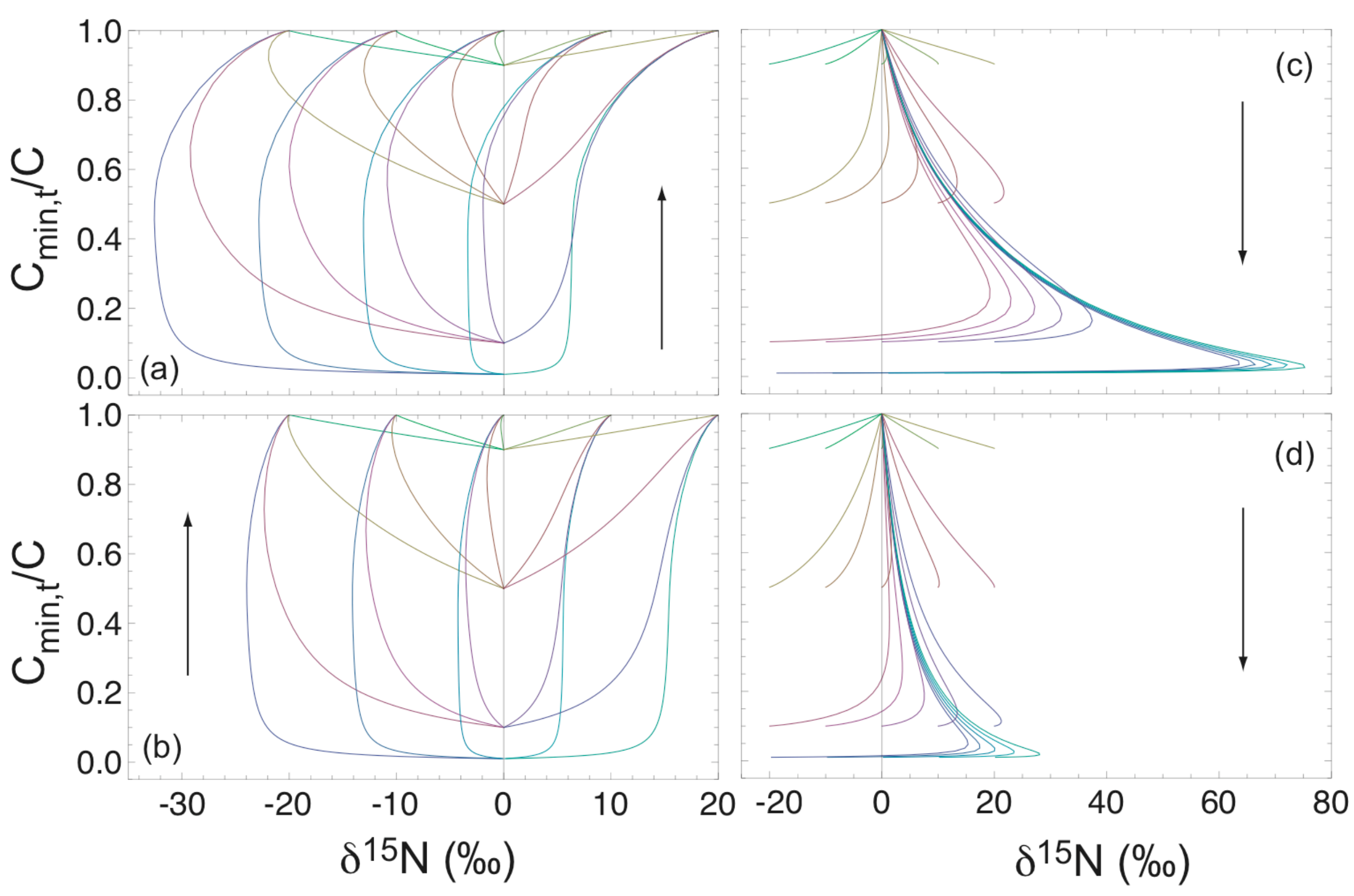

Figure 6 


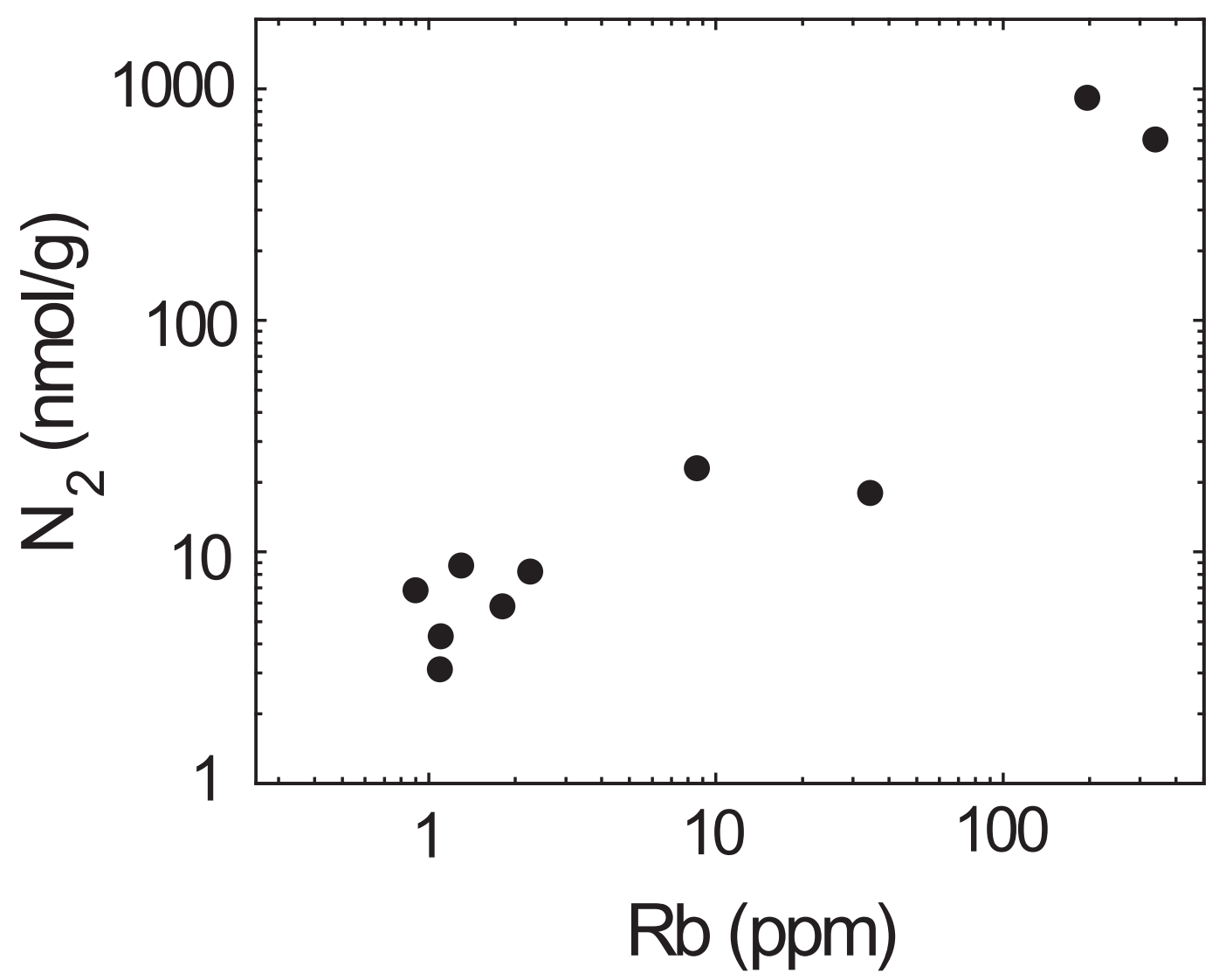

Figure 7 
Table 1

\begin{tabular}{|c|c|c|c|c|}
\hline & Name & Rock type & Mineral Assemblage & Notes \\
\hline \multicolumn{5}{|l|}{ Yemen } \\
\hline \multirow[t]{3}{*}{ Ataq } & JK3 & Spinel Lherzolite & $\mathrm{OI}, \mathrm{Cpx}, \mathrm{Opx}, \mathrm{Sp}, \mathrm{Am}$ & Modal metasomatism triggered by Afar plume \\
\hline & JK7 & Spinel Lherzolite & $\mathrm{OI}, \mathrm{Cpx}, \mathrm{Opx}, \mathrm{Sp}, \mathrm{Am}$ & Modal metasomatism triggered by Afar plume \\
\hline & JK8 & Spinel Lherzolite & $\mathrm{OI}, \mathrm{Cpx}, \mathrm{Opx}, \mathrm{Sp}, \mathrm{Am}$ & Modal metasomatism triggered by Afar plume \\
\hline Bir-Ali & BA8 & Spinel Lherzolite & $\mathrm{OI}, \mathrm{Cpx}, \mathrm{Opx}, \mathrm{Sp}$ & Unmetasomatized subcontinental mantle \\
\hline \multicolumn{5}{|l|}{ Eifel } \\
\hline \multirow[t]{2}{*}{ Meerfelder Marr } & MM2 & Spinel Harzburgite & OI, Cpx, Opx, Sp & Cryptic metasomatism related to Hercynian orogeny \\
\hline & MM13 & Spinel Lherzolite & OI, Cpx, Opx, Sp, Am & $\begin{array}{l}\text { Modal metasomatism related to Hercynian orogeny, an alteration by } \\
\text { Quaternary volcanism }\end{array}$ \\
\hline \multirow[t]{3}{*}{ Dreis Weiher } & DU25 & Spinel Harzburgite & OI, Cpx, Opx, Sp & Cryptic metasomatism related to Hercynian orogeny \\
\hline & DU24 & Spinel Wehrlite & $\mathrm{Ol}, \mathrm{Cpx}, \mathrm{Opx}, \mathrm{Sp}, \mathrm{Phl}$ & Interaction between Quaternary magma and wall rock \\
\hline & DU26 & Spinel Wehrlite & Ol, Cpx, Opx, Sp, Phl, Ap & Interaction between Quaternary magma and wall rock \\
\hline \multicolumn{5}{|l|}{ Massif Central } \\
\hline Fau & F100 & Spinel Harzburgite & $\mathrm{Ol}, \mathrm{Opx}, \mathrm{Am}, \mathrm{Phl}$ & $\begin{array}{l}\text { Modal metasomatism related to hercynian origenic events or toTertiary } \\
\text { and Quaternary volcanism }\end{array}$ \\
\hline
\end{tabular}


Table 2

\begin{tabular}{|c|c|c|c|c|c|c|c|}
\hline Sample & & $\mathrm{La} / \mathrm{Sm}$ & $\mathrm{Sm} / \mathrm{Zr}$ & ${ }^{87} \mathrm{Sr} /{ }^{36} \mathrm{Sr}$ & error & $\begin{array}{c}\mathrm{Sr} \\
\mathrm{ppm}\end{array}$ & $\begin{array}{c}\mathrm{Rb} \\
\mathrm{ppm}\end{array}$ \\
\hline JK3 & Whole Rock & & & & & & 3.23 \\
\hline JK7 & Whole Rock & & & & & & 1.26 \\
\hline BA8 & Whole Rock & & & & & & 0.5 \\
\hline MM2 & Whole Rock & 7.24 & 0.06 & & & & \\
\hline MM13 & Amphibole & 4.04 & 0.09 & & & & \\
\hline DU25 & Whole Rock & 5.01 & & & & & \\
\hline \multirow[t]{2}{*}{ DU24 } & Whole Rock & 1.43 & 0.03 & 0.703590 & 0.000022 & 59.1 & 34.5 \\
\hline & Clinopyroxene & 1.10 & 0.04 & 0.703571 & 0.000023 & 205.5 & 1.1 \\
\hline F100 & Amphibole & & & & & & 4.05 \\
\hline Host Basanite* & Whole Rock & 8.30 & & 0.703992 & 26 & 804 & 57.4 \\
\hline Primitive mantle ${ }^{* *}$ & & 1.60 & 0.04 & & & & \\
\hline
\end{tabular}

* Data from Stosch and Lugmair, 1986

** McDonough and Sun, 1995 
Table 3

\begin{tabular}{|c|c|c|c|c|c|c|c|c|c|c|c|}
\hline Name & Mineral & Stroke & $\begin{array}{c}\text { Quantity } \\
\mathrm{g} \\
\end{array}$ & $\begin{array}{l}{ }^{28} \mathrm{~N}_{2} \\
\mathrm{~mol} / \mathrm{g}\end{array}$ & error & $\begin{array}{l}{ }^{40} \mathrm{Ar} \\
\mathrm{mol} / \mathrm{g}\end{array}$ & error & ${ }^{40} \mathrm{Ar} /{ }^{36} \mathrm{Ar}$ & error & $\mathrm{N}_{2}{ }^{140} \mathrm{Ar}$ & error \\
\hline JK2O & $\mathrm{OL}$ & 100 & 0.25 & $2.6 \mathrm{E}-10$ & $1.8 \mathrm{E}-11$ & 2.2E-12 & $2.4 \mathrm{E}-13$ & 589.3 & 33.6 & 120.8 & 15.7 \\
\hline JK3O & $\mathrm{OL}$ & 100 & 0.27 & 2.1E-10 & $1.5 \mathrm{E}-11$ & $2.3 \mathrm{E}-12$ & $2.6 \mathrm{E}-13$ & 360.1 & 20.5 & 92.1 & 12.0 \\
\hline JK7O & $\mathrm{OL}$ & 100 & 0.22 & $9.8 \mathrm{E}-11$ & $6.8 \mathrm{E}-12$ & & & & & & \\
\hline JK7P & & 100 & 0.28 & $8.9 \mathrm{E}-10$ & $6.2 \mathrm{E}-11$ & $5.9 \mathrm{E}-12$ & $6.5 \mathrm{E}-13$ & 926.2 & 52.8 & 151.3 & 19.6 \\
\hline JK8O & OL & 100 & 0.27 & $1.9 \mathrm{E}-10$ & $1.3 \mathrm{E}-11$ & $1.9 \mathrm{E}-12$ & $2.1 \mathrm{E}-13$ & 410.1 & 23.4 & 96.9 & 12.6 \\
\hline BA8O & OL & 100 & 0.22 & 2.3E-11 & $1.6 \mathrm{E}-12$ & b.l. & & & & & \\
\hline BA8P & CPX & 100 & 0.25 & $1.5 \mathrm{E}-10$ & 1.0E-11 & b.l. & & & & & \\
\hline DU25P & CPX & 50 & 0.31 & $8.6 \mathrm{E}-10$ & $5.9 \mathrm{E}-11$ & $1.5 \mathrm{E}-11$ & $1.6 \mathrm{E}-12$ & 4669.7 & 266.2 & 57.7 & 7.5 \\
\hline DU25P2 & CPX & 100 & 0.31 & $8.9 \mathrm{E}-10$ & $6.1 \mathrm{E}-11$ & 1.6E-11 & $1.7 \mathrm{E}-12$ & 7417.9 & 422.8 & 56.7 & 7.4 \\
\hline
\end{tabular}


Table 4

\begin{tabular}{|c|c|c|c|c|c|c|c|c|}
\hline & $\begin{array}{c}\text { Weight } \\
\mathrm{g}\end{array}$ & $\begin{array}{c}\text { Temperature } \\
{ }^{\circ} \mathrm{C} \\
\end{array}$ & $\begin{array}{l}{ }^{28} \mathrm{~N}_{2} \\
\mathrm{~mol} / \mathrm{g}\end{array}$ & $\begin{array}{c}\delta^{15} \mathrm{~N} \\
\% 0\end{array}$ & error & $\begin{array}{l}{ }^{40} \mathrm{Ar} \\
\mathrm{mol} / \mathrm{g}\end{array}$ & ${ }^{40} \mathrm{Ar} /{ }^{36} \mathrm{Ar}$ & error \\
\hline JK7B & 0.7597 & 700 & 2.2E-08 & 0.2 & 1.9 & $3.8 \mathrm{E}-12$ & 396.2 & 11.0 \\
\hline \multirow{6}{*}{ Whole Rock } & 0.7597 & 800 & 6.5E-09 & 3.9 & 2.1 & $9.7 \mathrm{E}-13$ & 564.8 & 24.1 \\
\hline & 0.7597 & 900 & 7.4E-09 & 5.8 & 1.8 & $9.5 \mathrm{E}-13$ & 582.6 & 32.1 \\
\hline & 0.7597 & 1100 & 5.7E-09 & 13.5 & 3.0 & $6.1 \mathrm{E}-13$ & 848.3 & 123.8 \\
\hline & & Total & 4.1E-08 & 3.6 & 1.2 & 6.3E-12 & 493.7 & 57.9 \\
\hline & & $>900$ & 1.3E-08 & 9.2 & 0.5 & 1.6E-12 & 686.0 & 27.2 \\
\hline & & $>800$ & 2.0E-08 & 7.4 & 0.6 & $2.5 \mathrm{E}-12$ & 639.4 & 32.5 \\
\hline JK7U & 0.7902 & 700 & 6.7E-09 & 5.4 & 5.5 & $8.9 \mathrm{E}-12$ & 328.0 & 5.1 \\
\hline \multirow{9}{*}{ Whole Rock } & 0.7902 & 800 & $6.2 \mathrm{E}-09$ & 11.4 & 1.4 & $1.2 \mathrm{E}-12$ & 415.7 & 13.2 \\
\hline & 0.7902 & 900 & 5.3E-09 & 13.7 & 1.2 & $9.6 \mathrm{E}-13$ & 437.8 & 20.5 \\
\hline & 0.7902 & 1100 & 3.1E-09 & 19.7 & 2.2 & 1.6E-12 & 532.9 & 41.9 \\
\hline & 0.7902 & 1600 & 5.2E-09 & 7.7 & 2.2 & bl & & \\
\hline & 0.7902 & 1600 & 2.0E-09 & 9.2 & 1.9 & bl & & \\
\hline & & Total & $2.8 \mathrm{E}-08$ & 10.5 & 1.4 & $1.3 \mathrm{E}-11$ & 370.1 & 49.8 \\
\hline & & Melting & 7.3E-09 & 8.1 & 0.4 & & & \\
\hline & & $>800$ & 2.2E-08 & 12.0 & 0.6 & 3.7E-12 & 471.9 & 17.7 \\
\hline & & $>900$ & 1.6E-08 & 12.3 & 0.5 & $2.6 \mathrm{E}-12$ & 497.3 & 16.0 \\
\hline JK8B & 0.418 & 400 & 1.4E-09 & 1.2 & 4.1 & 1.4E-12 & 324.0 & 8.5 \\
\hline \multirow[t]{11}{*}{ Whole Rock } & 0.418 & 600 & 8.7E-10 & & & $9.0 \mathrm{E}-13$ & 267.1 & 9.7 \\
\hline & 0.418 & 700 & 1.2E-09 & 4.4 & 1.7 & $6.8 \mathrm{E}-13$ & 489.2 & 36.8 \\
\hline & 0.418 & 800 & 4.6E-09 & 7.3 & 1.3 & $2.8 \mathrm{E}-12$ & 349.4 & 9.3 \\
\hline & 0.418 & 900 & 1.0E-08 & 9.1 & 1.2 & $2.3 \mathrm{E}-12$ & 372.0 & 14.6 \\
\hline & 0.418 & 1100 & 4.3E-09 & 8.8 & 1.5 & $3.2 \mathrm{E}-12$ & 441.0 & 33.1 \\
\hline & 0.418 & 1600 & 4.8E-09 & 10.2 & 1.5 & $\mathrm{bl}$ & & \\
\hline & 0.418 & 1600 & 1.2E-09 & 11.8 & 2.7 & $\mathrm{bl}$ & & \\
\hline & & Total & $2.8 \mathrm{E}-08$ & 8.2 & 0.6 & 1.1E-11 & 378.5 & 37.2 \\
\hline & & Melting & 6.0E-09 & 10.5 & 0.3 & & & \\
\hline & & $>900$ & 2.0E-08 & 9.4 & 0.6 & $5.5 \mathrm{E}-12$ & 412.4 & 30.7 \\
\hline & & $>800$ & $2.5 \mathrm{E}-08$ & 9.0 & 0.6 & 8.3E-12 & 391.0 & 35.4 \\
\hline BA8U & 0.6672 & 700 & 9.2E-09 & 0.2 & 2.0 & 3.5E-12 & 315.5 & 6.0 \\
\hline \multirow[t]{9}{*}{ Whole Rock } & 0.6672 & 800 & 8.2E-09 & 3.0 & 1.3 & 7.7E-13 & 375.9 & 18.2 \\
\hline & 0.6672 & 900 & 1.7E-08 & 8.0 & 1.2 & $1.2 \mathrm{E}-12$ & 372.7 & 16.9 \\
\hline & 0.6672 & 1100 & 8.3E-09 & 6.7 & 1.3 & $9.9 \mathrm{E}-13$ & 556.6 & 66.1 \\
\hline & 0.6672 & 1600 & 4.2E-09 & 9.7 & 1.8 & bl & & \\
\hline & 0.6672 & 1600 & & & & $\mathrm{bl}$ & & \\
\hline & & Total & 4.7E-08 & 5.5 & 0.7 & $6.4 \mathrm{E}-12$ & 370.3 & 43.2 \\
\hline & & Melting & 4.2E-09 & 9.7 & 0.2 & & & \\
\hline & & $>800$ & 3.8E-08 & 6.8 & 0.6 & $2.9 \mathrm{E}-12$ & 435.7 & 26.0 \\
\hline & & $>900$ & 3.0E-08 & 7.9 & 0.5 & $2.2 \mathrm{E}-12$ & 456.9 & 24.3 \\
\hline MM2B & 0.8687 & 700 & 8.6E-09 & -1.3 & 2.0 & $9.6 \mathrm{E}-13$ & 379.4 & 12.9 \\
\hline \multirow[t]{5}{*}{ Whole Rock } & 0.8687 & 800 & 2.3E-09 & 11.6 & 2.2 & $4.8 \mathrm{E}-13$ & 653.4 & 36.9 \\
\hline & 0.8687 & 900 & 3.3E-10 & 9.4 & 6.6 & $1.2 \mathrm{E}-12$ & 541.5 & 21.0 \\
\hline & 0.8687 & $1100 \mathrm{bl}$ & & & & bl & & \\
\hline & & Total & 1.1E-08 & 1.6 & 1.6 & $2.6 \mathrm{E}-12$ & 503.1 & 62.5 \\
\hline & & $>900$ & 3.3E-10 & 9.4 & 0.2 & $1.2 \mathrm{E}-12$ & 541.5 & 50.0 \\
\hline MM2U & 0.9141 & 800 & 1.9E-09 & 2.7 & 2.1 & $9.0 \mathrm{E}-13$ & 472.6 & 16.1 \\
\hline \multirow[t]{7}{*}{ Whole Rock } & 0.9141 & 900 & $3.2 \mathrm{E}-10$ & 7.6 & 2.1 & $2.5 \mathrm{E}-13$ & 1006.1 & 89.1 \\
\hline & 0.9141 & 1600 & 2.2E-09 & 6.7 & 1.5 & bl & & \\
\hline & 0.9141 & 1600 & 3.7E-10 & -3.2 & 3.4 & bl & & \\
\hline & 0.9141 & 1600 & $2.2 \mathrm{E}-10$ & -10.0 & 6.4 & bl & & \\
\hline & & Total & 5.0E-09 & 3.8 & 1.1 & 1.1E-12 & 586.8 & 88.9 \\
\hline & & Melting & 2.8E-09 & 4.1 & 0.8 & & & \\
\hline & & $>900$ & 3.1E-09 & 4.4 & 0.8 & $2.5 \mathrm{E}-13$ & 1006.1 & 47.1 \\
\hline MM13C & 0.2018 & 700 & 3.1E-09 & 6.6 & 1.4 & $9.5 \mathrm{E}-13$ & 806.7 & 79.3 \\
\hline \multirow[t]{3}{*}{ Clinopyroxene } & 0.2018 & 900 & 4.7E-10 & 1.7 & 2.4 & $4.5 \mathrm{E}-13$ & 822.8 & 142.1 \\
\hline & 0.2018 & 1100 & 1.6E-09 & 0.4 & 1.8 & 1.7E-11 & 359.4 & 13.6 \\
\hline & 0.2018 & 1600 & 5.7E-09 & 11.0 & 1.8 & bl & & \\
\hline
\end{tabular}




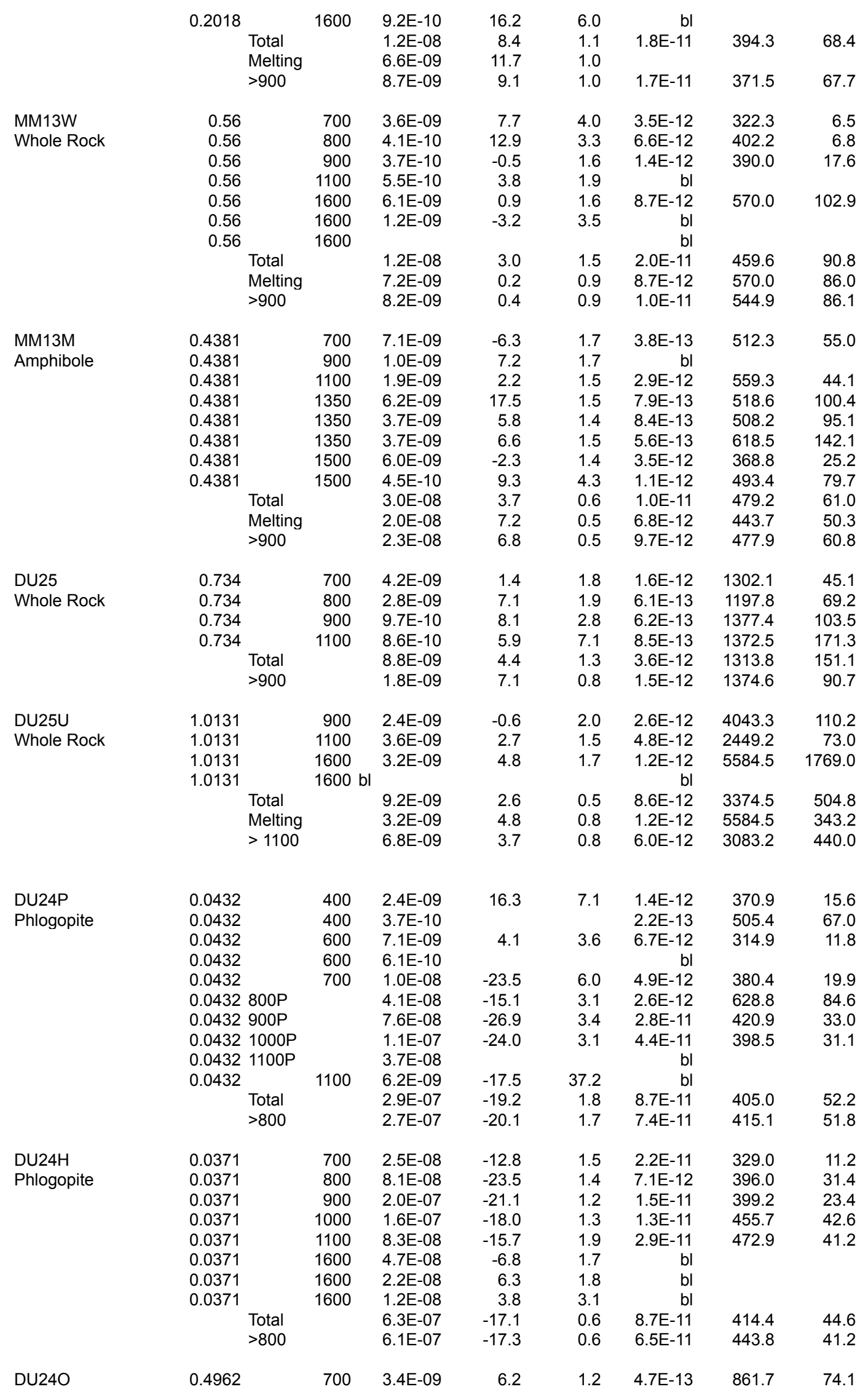




\begin{tabular}{|c|c|c|c|c|c|c|c|c|c|}
\hline \multirow[t]{8}{*}{ Olivine } & 0.4962 & & 800 & 1.2E-09 & 9.0 & 1.3 & $3.1 \mathrm{E}-13$ & 1062.0 & 118.9 \\
\hline & 0.4962 & & 900 & 5.3E-10 & 10.3 & 2.8 & $2.4 \mathrm{E}-13$ & 1181.6 & 183.0 \\
\hline & 0.4962 & & 1100 & $8.2 \mathrm{E}-10$ & 2.5 & 2.2 & $\mathrm{bl}$ & & \\
\hline & 0.4962 & & 1600 & 2.1E-09 & 9.8 & 1.8 & $\mathrm{bl}$ & & \\
\hline & 0.4962 & & 1600 & $5.7 \mathrm{E}-10$ & 7.1 & 3.8 & bl & & \\
\hline & \multicolumn{3}{|c|}{ Total } & 7.9E-09 & 7.4 & 0.8 & $1.0 \mathrm{E}-12$ & 997.0 & 133.6 \\
\hline & \multicolumn{3}{|c|}{ Melting } & 2.1E-09 & 9.8 & 0.5 & & & \\
\hline & \multicolumn{3}{|c|}{$>900$} & 3.4E-09 & 8.1 & 0.6 & $2.4 \mathrm{E}-13$ & 1181.6 & 69.0 \\
\hline DU24C & 0.4548 & & 700 & $1.5 \mathrm{E}-09$ & 6.1 & 1.4 & $2.4 \mathrm{E}-12$ & 514.1 & 14.6 \\
\hline \multirow{9}{*}{ Clinopyroxene } & 0.4548 & & 800 & $7.9 \mathrm{E}-10$ & 7.1 & 1.6 & $1.5 \mathrm{E}-13$ & 908.7 & 154.4 \\
\hline & 0.4548 & & 900 & $3.7 \mathrm{E}-10$ & 8.4 & 3.3 & 8.7E-13 & 467.7 & 35.4 \\
\hline & 0.4548 & & 1000 & $8.9 \mathrm{E}-10$ & -2.9 & 1.5 & $1.3 \mathrm{E}-12$ & 717.2 & 60.0 \\
\hline & 0.4548 & & 1100 & 1.7E-09 & -2.9 & 1.7 & 3.2E-12 & 593.1 & 42.5 \\
\hline & 0.4548 & & 1600 & 1.4E-09 & 12.5 & 2.4 & $9.5 \mathrm{E}-12$ & 1296.4 & 331.2 \\
\hline & 0.4548 & & $1600 \mathrm{bl}$ & & & & bl & & \\
\hline & & \multicolumn{2}{|l|}{ Total } & 6.7E-09 & 4.1 & 0.8 & 1.7E-11 & 972.9 & 281.2 \\
\hline & & \multicolumn{2}{|l|}{ Melting } & 1.4E-09 & 12.5 & 0.5 & $9.5 \mathrm{E}-12$ & 1296.4 & 279.6 \\
\hline & & \multicolumn{2}{|l|}{$>900$} & 4.3E-09 & 2.9 & 0.7 & $1.5 \mathrm{E}-11$ & 1046.8 & 280.8 \\
\hline DU24B & 0.5817 & & 600 & 9.7E-09 & 4.1 & 1.8 & $8.2 \mathrm{E}-13$ & 386.4 & 15.9 \\
\hline \multirow[t]{8}{*}{ Whole Rock } & 0.5817 & & 700 & 4.0E-09 & 11.9 & 2.1 & $2.7 \mathrm{E}-13$ & 566.9 & 64.6 \\
\hline & 0.5817 & & 900 & 7.0E-09 & -4.3 & 1.9 & 7.2E-13 & 581.7 & 45.9 \\
\hline & 0.5817 & & 1100 & $6.0 \mathrm{E}-09$ & -6.5 & 2.5 & 8.3E-13 & 777.7 & 111.3 \\
\hline & 0.3311 & & 1600 & $4.9 \mathrm{E}-09$ & -12.5 & 2.8 & bl & & \\
\hline & 0.3311 & & $1600 \mathrm{bl}$ & & & & $\mathrm{bl}$ & & \\
\hline & & \multicolumn{2}{|l|}{ Total } & $3.2 \mathrm{E}-08$ & -1.4 & 1.0 & $2.6 \mathrm{E}-12$ & 581.0 & 74.5 \\
\hline & & \multicolumn{2}{|l|}{ Melting } & $4.9 \mathrm{E}-09$ & -12.5 & 0.4 & & & \\
\hline & & \multicolumn{2}{|l|}{$>900$} & $1.8 \mathrm{E}-08$ & -7.3 & 0.8 & $1.5 \mathrm{E}-12$ & 686.4 & 69.1 \\
\hline DU26B & 1.0209 & & 700 & 8.4E-09 & 8.2 & 2.1 & 4.2E-13 & 436.8 & 25.8 \\
\hline \multirow[t]{8}{*}{ Whole Rock } & 1.0209 & & 800 & $3.8 \mathrm{E}-09$ & 9.3 & 2.8 & $2.6 \mathrm{E}-13$ & 838.5 & 68.6 \\
\hline & 1.0209 & & 900 & 2.1E-09 & -5.5 & 2.3 & $1.8 \mathrm{E}-13$ & 985.0 & 125.8 \\
\hline & 1.0209 & & 1100 & 2.1E-09 & -6.7 & 3.3 & $3.5 \mathrm{E}-13$ & 902.8 & 146.7 \\
\hline & 0.5866 & & 1600 & $7.1 \mathrm{E}-10$ & -8.4 & 3.2 & bl & & \\
\hline & 0.5866 & & 1600 & $8.6 \mathrm{E}-10$ & 3.1 & 2.5 & $\mathrm{bl}$ & & \\
\hline & & Total & & $1.8 \mathrm{E}-08$ & 4.1 & 1.3 & $1.2 \mathrm{E}-12$ & 738.4 & 90.6 \\
\hline & & Melting & & 1.6E-09 & -2.1 & 0.2 & & & \\
\hline & & $>900$ & & $5.8 \mathrm{E}-09$ & -5.0 & 0.5 & 5.3E-13 & 930.8 & 75.4 \\
\hline DU26P & 0.0349 & & 700 & 4.7E-08 & 2.8 & 1.3 & $1.5 \mathrm{E}-11$ & 366.9 & 17.9 \\
\hline Phlogopite & 0.0349 & & 800 & 7.7E-08 & -7.7 & 1.4 & $1.9 \mathrm{E}-12$ & 727.0 & 123.5 \\
\hline & 0.0349 & & 900 & 3.4E-07 & -5.2 & 1.3 & 8.6E-12 & 440.7 & 40.1 \\
\hline & 0.0349 & & 1000 & 2.1E-07 & -1.9 & 1.3 & $5.4 \mathrm{E}-12$ & 734.9 & 116.5 \\
\hline & 0.0349 & & 1100 & $1.4 \mathrm{E}-07$ & -3.7 & 1.2 & 1.7E-11 & 588.4 & 75.1 \\
\hline & 0.0349 & & 1350 & 7.4E-08 & 2.9 & 1.8 & bl & & \\
\hline & 0.0349 & & 1350 & 1.6E-08 & 7.2 & 2.2 & bl & & \\
\hline & 0.0349 & & 1350 & 5.7E-08 & 7.1 & 1.8 & $\mathrm{bl}$ & & \\
\hline & & Total & & $9.6 \mathrm{E}-07$ & -2.5 & 0.6 & 4.7E-11 & 515.6 & 61.7 \\
\hline & & $>800$ & & $9.2 \mathrm{E}-07$ & -2.8 & 0.6 & 3.3E-11 & 582.0 & 57.2 \\
\hline F100P & 0.0321 & & 700 & 1.3E-07 & -4.0 & 1.3 & 2.6E-11 & 325.9 & 11.0 \\
\hline Phlogopite & 0.0321 & & 800 & 7.5E-08 & 0.6 & 1.7 & 1.6E-11 & 334.7 & 16.5 \\
\hline & 0.0321 & & 900 & $1.8 \mathrm{E}-07$ & 1.5 & 1.7 & $2.8 \mathrm{E}-11$ & 360.8 & 14.8 \\
\hline & 0.0321 & & 1000 & $1.8 \mathrm{E}-07$ & 5.6 & 1.9 & $1.4 \mathrm{E}-10$ & 356.6 & 7.4 \\
\hline & 0.0321 & & 1100 & $9.3 \mathrm{E}-08$ & 2.9 & 1.6 & $6.2 \mathrm{E}-11$ & 475.6 & 26.9 \\
\hline & 0.0321 & & 1350 & 4.7E-08 & 7.8 & 1.3 & $4.8 \mathrm{E}-11$ & 550.8 & 37.9 \\
\hline & 0.0321 & & 1350 & $2.9 \mathrm{E}-08$ & 7.1 & 1.6 & 2.3E-11 & 467.4 & 56.9 \\
\hline & 0.0321 & & 1350 & 6.6E-09 & 6.8 & 3.7 & 1.4E-11 & 535.0 & 88.4 \\
\hline & & Total & & 7.4E-07 & 2.3 & 0.7 & $3.5 \mathrm{E}-10$ & 414.8 & 42.7 \\
\hline & & $>800$ & & $6.1 \mathrm{E}-07$ & 3.6 & 0.7 & 3.3E-10 & 421.8 & 42.4 \\
\hline F100B & 0.693 & & 700 & 4.1E-08 & 1.1 & 1.9 & 1.1E-12 & 314.0 & 11.6 \\
\hline Whole Rock & 0.693 & & 800 & 3.6E-09 & 3.0 & 1.6 & $1.2 \mathrm{E}-13$ & 1013.2 & 157.2 \\
\hline & 0.693 & & 900 & 1.8E-09 & 2.5 & 1.9 & $1.4 \mathrm{E}-13$ & 988.0 & 165.0 \\
\hline & 0.693 & & 1100 & $1.5 \mathrm{E}-09$ & -0.8 & 1.4 & bl & & \\
\hline & 0.693 & & 1600 & 2.1E-09 & 5.9 & 1.8 & $4.9 \mathrm{E}-12$ & 1072.4 & 287.3 \\
\hline & 0.693 & & 1600 & 1.0E-09 & 8.7 & 2.2 & bl & & \\
\hline & 0.693 & & 1600 & 2.6E-09 & 12.8 & 1.7 & $\mathrm{bl}$ & & \\
\hline
\end{tabular}




\begin{tabular}{|c|c|c|c|c|c|c|c|c|}
\hline & & Total & 5.3E-08 & 2.1 & 1.5 & $6.3 \mathrm{E}-12$ & 936.0 & 337.7 \\
\hline & & Melting & 5.7E-09 & 9.5 & 0.1 & $4.9 \mathrm{E}-12$ & 1072.4 & 337.5 \\
\hline & & $>900$ & 9.0E-09 & 6.4 & 0.1 & 5.0E-12 & 1070.1 & 337.5 \\
\hline & 0.3981 & 700 & 8.5E-08 & -8.0 & 1.4 & $4.9 \mathrm{E}-11$ & 338.5 & 5.1 \\
\hline \multirow{8}{*}{ Amphibole } & 0.3981 & 900 & 2.3E-07 & 6.2 & 2.2 & 1.2E-11 & 325.1 & 5.6 \\
\hline & 0.3981 & 1100 & $5.5 \mathrm{E}-08$ & 8.1 & 1.2 & $1.5 \mathrm{E}-10$ & 344.7 & 5.2 \\
\hline & 0.3981 & 1400 & $1.9 \mathrm{E}-07$ & 4.1 & 1.7 & 3.6E-11 & 875.8 & 24.9 \\
\hline & 0.3981 & 1400 & 2.0E-09 & 3.7 & 2.2 & 2.2E-12 & 1493.0 & 319.7 \\
\hline & 0.3981 & 1400 & 2.9E-09 & 4.2 & 1.5 & 4.7E-12 & 941.1 & 126.9 \\
\hline & \multicolumn{2}{|c|}{ Total } & $5.6 \mathrm{E}-07$ & 3.5 & 1.1 & 2.6E-10 & 438.6 & 57.6 \\
\hline & & Melting & $1.9 \mathrm{E}-07$ & 4.1 & 0.6 & 4.3E-11 & 913.8 & 38.1 \\
\hline & & $>1100$ & $2.5 \mathrm{E}-07$ & 5.0 & 0.6 & $1.9 \mathrm{E}-10$ & 470.5 & 56.0 \\
\hline
\end{tabular}

